\title{
Decreased photosynthetic rate under high temperature in wheat is due to lipid desaturation, oxidation, acylation, and damage of organelles
}

\author{
M. Djanaguiraman ${ }^{1,3}$, D. L. Boyle ${ }^{2}$, R. Welti ${ }^{2}$, S. V. K. Jagadish ${ }^{1}$ and P. V. V. Prasad ${ }^{1 *}$ (i)
}

\begin{abstract}
Background: High temperature is a major abiotic stress that limits wheat (Triticum aestivum L.) productivity. Variation in levels of a wide range of lipids, including stress-related molecular species, oxidative damage, cellular organization and ultrastructural changes were analyzed to provide an integrated view of the factors that underlie decreased photosynthetic rate under high temperature stress. Wheat plants of cultivar Chinese Spring were grown at optimum temperatures $\left(25 / 15^{\circ} \mathrm{C}\right.$, maximum/minimum) until the onset of the booting stage. Thereafter, plants were exposed to high temperature $\left(35 / 25^{\circ} \mathrm{C}\right)$ for $16 \mathrm{~d}$.

Results: Compared with optimum temperature, a lower photosynthetic rate was observed at high temperature which is an interplay between thylakoid membrane damage, thylakoid membrane lipid composition, oxidative damage of cell organelle, and stomatal and non-stomatal limitations. Triacylglycerol levels were higher under high temperature stress. Polar lipid fatty acyl unsaturation was lower at high temperature, while triacylglycerol unsaturation was the same at high temperature and optimum temperature. The changes in lipid species indicates increases in activities of desaturating, oxidizing, glycosylating and acylating enzymes under high temperature stress. Cumulative effect of high temperature stress led to generation of reactive oxygen species, cell organelle and membrane damage, and reduced antioxidant enzyme activity, and imbalance between reactive oxygen species and antioxidant defense system.
\end{abstract}

Conclusions: Taken together with recent findings demonstrating that reactive oxygen species are formed from and are removed by thylakoid lipids, the data suggest that reactive oxygen species production, reactive oxygen species removal, and changes in lipid metabolism contribute to decreased photosynthetic rate under high temperature stress.

Keywords: Anatomy, High temperature, Lipids, Oxidative damage, Photosynthesis, Wheat

\section{Background}

Wheat (Triticum aestivum L.) is grown in about $30 \%$ of the world's area cultivated with cereals, occupying over 220 million hectares worldwide of which $50 \%$ of the area experiences high temperature (HT) stress [1]. In fact, global mean surface air temperature has increased by $0.8^{\circ}$ $\mathrm{C}$ in the twentieth century and is predicted to increase further by $3-5{ }^{\circ} \mathrm{C}$ by the end of twenty-first century [2].

\footnotetext{
*Correspondence: vara@ksu.edu

'Department of Agronomy, 2004 Throckmorton Plant Sciences Center,

Kansas State University, Manhattan, KS 66506, USA

Full list of author information is available at the end of the article
}

An increase in number of hot days and temperature variability is also predicted. Wheat is very sensitive to HT during its floral development and grain-filling phase [3, 4]. The optimal temperature (OT) for anthesis and grain filling ranges from 12 to $22{ }^{\circ} \mathrm{C}$ for wheat [5], and grain yield is significantly reduced with HT [6]. Keeping in view the predicted increase in growing season temperature in wheat producing areas, it is important to understand mechanisms of HT tolerance in wheat to maintain and improve yield potential.

HT stress causes damage to thylakoid membranes [7] and decreases photosystem II (PSII) quantum yield $[8,9]$ 
and photosynthesis [10]. Apart from this, HT increases production of reactive oxygen species (ROS) including superoxide radical $\left(\mathrm{O}_{2}^{-}\right)$and hydrogen peroxide $\left(\mathrm{H}_{2} \mathrm{O}_{2}\right)$ and increase lipid peroxidation and cause membrane damage [11]. Elevated temperatures decrease the activities of antioxidant enzymes like superoxide dismutase (SOD), catalase (CAT) and peroxidase (POX) [11-13]. The impacts of HT stress on leaf level photosynthesis is known, however, the mechanisms driving tolerance or susceptibility based on various membrane lipid species (polar lipids, triacylglycerol, oxidized lipids and acylated galactolipids), ultrastructure of cell organelles and its association with oxidants and antioxidant enzyme activity are not well understood.

Membranes are the targets of HT stress and membrane lipid composition is a crucial factor for temperature tolerance or susceptibility. The membrane plays important roles in sensing environmental change, signal transduction and substance metabolism. The thylakoid membranes are the location for the light-dependent reactions for photosynthesis. In wheat, galactolipids (monogalactosyldiacylglycerol; MGDG and digalactosyldiacylglycerol; DGDG) are the major chloroplast lipids, and trienoic species of MGDG and DGDG are highly vulnerable to peroxidation by ROS and by lipoxygenase $[14,15]$. The fate of these lipid species under HT stress is not fully understood. Additionally, membranes may serve both as sources of ROS during plant stress and as reservoirs to take up ROS [15-18]. In Arabidopsis, oxidized lipids are produced enzymatically through the action of lipoxygenase as well as non-enzymatically through the action of ROS [19]. Similar to ROS, oxidized lipids may act as signaling molecules that initiate stress responses in plants [20-24]. Earlier studies have shown that triacylglycerols (TAGs) are accumulated under HT stress [25]; however, the changes in the saturation index of these TAG under HT stress are not known.

Several studies indicate that HT stress increases membrane damage and decreases antioxidant levels in wheat at the seedling stage [26-29], anthesis stage [30], or grain filing stage [31]. Temperature-induced changes in membrane fluidity is one of the immediate consequences of temperature changes, including HT stress, in plants $[32,33]$. The significance of membrane fluidity in temperature tolerance has been elucidated by mutation analysis and transgenic and physiological studies. In soybean, a mutant deficient in fatty acid unsaturation showed strong tolerance to HT [34]. Similarly, the thylakoid membranes of an Arabidopsis mutants deficient in $\omega-6$ fatty acid unsaturation (fad6) showed increased stability at HT [35], and decreased lipid unsaturation in tobacco caused by silencing an $\omega-3$ desaturase gene rendered the plants more tolerant to HT [36].

Although leaf ultrastructural changes may reflect the effects of HT stress, there is scant description of the anatomical and ultrastructural changes in wheat leaves under HT stress. High temperature stress increased the thicknesses of the palisade and spongy layers, and disrupted the plasma, chloroplast, and thylakoid membranes in soybean leaves leading to lack to integrity [37]. Disorganized thylakoids with a reduced thickness of grana stacking, decreased size of starch granule and increased numbers of plastoglobules [38], empty mitochondria and damaged PSII [39] have been observed under HT stress in grape leaves. Corresponding observations of wheat leaf anatomy have not been well explored and less understood.

HT during the wheat reproductive stage causes decreased seed set, grain number, grain filling duration, grain filling rate and individual grain weight [40-43]. Together, the effects of HT stress result in decreased grain yield and harvest index [5, 41, 42, 44, 45]. In this study, various physiological and anatomical parameters that can change under HT stress, namely oxidants, antioxidant enzyme activities, cell organelle structure, and corresponding lipid changes, are quantified to determine the mechanisms that decrease photosynthetic rate under HT stress. The study fills a knowledge gap by ascertaining the series of physiological changes, by recording wheat leaf ultrastructural changes caused by HT, and by linking these with biochemical changes related to polar, oxidized, and neutral lipids.

\section{Methods}

Two independent experiments using Chinese Spring were conducted in controlled-environment facilities at Kansas State University, Department of Agronomy, Manhattan, KS, USA.

\section{Plant husbandry and growth conditions}

Seeds of Chinese Spring wheat were sown at 4-cm depth in $1.8 \mathrm{~L}$ pots (pot diameter at the top and the bottom was 21 and $16 \mathrm{~cm}$, respectively; pot depth was $20 \mathrm{~cm}$ ) containing commercial Sun Grow Metro Mix 200 potting soil (Hummert International, Topeka, KS, USA). After emergence, plants were thinned to two plants per pot and maintained until maturity. A systemic insecticide, Marathon 1\% G (granules) (i.e., Imidacloprid,1-[(6chloro-3-pyridinyl)methyl]-N-nitro-2-imidazolidinimine, Hummert International, Topeka, KS, USA), was applied to each pot at $4 \mathrm{~g}$ per pot. The medium was fertilized with Osmocote at $5 \mathrm{~g} \mathrm{pot}^{-1}$ (controlled release plant food, 14:14:14\% N: $\mathrm{P}_{2} \mathrm{O}_{5}: \mathrm{K}_{2} \mathrm{O}$, respectively; Hummert International, Topeka, KS, USA) before sowing. Plants were watered daily to avoid water stress. The seedlings were grown in growth chambers (Conviron Model E15, Winnipeg, MB, Canada) maintained at optimum temperature (OT; $25 / 15{ }^{\circ} \mathrm{C}$ daytime maximum/nighttime minimum temperature), 14-h photoperiod, and $80-85 \%$ 
relative humidity. Each growth chamber was $136 \mathrm{~cm}$ wide, $246 \mathrm{~cm}$ long, and $180 \mathrm{~cm}$ high. The temperature regimes, i.e., the daytime maximum and nighttime minimum temperatures, were each held for $8 \mathrm{~h}$; the transition periods between maximum and minimum temperatures were each $4 \mathrm{~h}$. In all growth chambers, the canopy-level, photosynthetically-active radiation was about $900 \mu \mathrm{mol} \mathrm{m} \mathrm{m}^{-2} \mathrm{~s}^{-1}$ provided by cool white fluorescent lamps (Philips Lighting Co., Somerset, NJ, USA). Plants in each growth chamber were randomly moved once in every $7 \mathrm{~d}$ to avoid positional effects within the chamber. To avoid water stress, all pots were kept in trays containing about 2-cm deep water from sowing to maturity.

At the completion of booting stage (Feekes growth stage 10.0), the plants were transferred to OT $\left(25 / 15^{\circ} \mathrm{C}\right.$, daytime maximum /nighttime minimum temperature, $25{ }^{\circ} \mathrm{C}$ : OT for spikelet initiation and anthesis [46]) or HT $\left(35 / 25{ }^{\circ} \mathrm{C}\right.$ daytime maximum /nighttime minimum temperature, $>34$ ${ }^{\circ} \mathrm{C}$ : critical maximum temperature [47]. Apart from this, the OT thresholds for spring wheat was estimated to be 18 and $34{ }^{\circ} \mathrm{C}$; above which an additional degree day is associated with a $\sim 7 \%$ yield reduction]. The temperature treatments were randomly assigned to two growth chambers. Each growth chamber had 30 pots (60 plants). Out of these 60 plants, 40 plants were used for the measurement of physiological and biochemical traits at regular intervals (3 d), and ten plants were used to collect samples for lipid extraction and anatomical studies. The remaining ten plants were used for analyzing yield and yield components. For each physiological and biochemical measurement, five plants were individual replicates and the final number of samples was ten $(5$ plants $\times 2$ experiments; $n=10)$. For lipid and anatomy studies, there were ten replications (5 plants $\times 2$ experiments; $n=10$ ). Yield and its components were the mean of 20 observations ( 10 plants $\times 2$ experiments; $n=20$ ). During the stress period, the position of pots was changed randomly every day in all growth chambers to avoid positional effects. The plants were maintained in the HT regime for $16 \mathrm{~d}$. After that, they were returned to the original growth chamber (OT: $25 / 15{ }^{\circ} \mathrm{C}$ ), where they remained till maturity. In both temperature regimes, day-maximum and night-minimum temperatures were held for $8 \mathrm{~h}$, and the transition period between maximum and minimum temperatures was $4 \mathrm{~h}$. Relative humidity in all growth chambers was set and maintained at $70-80 \%$. In the future, it is predicted that increased temperature will be observed; however, the relative humidity will remain constant [48]. Air temperature and relative humidity were continuously monitored at $15-\mathrm{min}$ intervals in all growth chambers throughout the experiment using a $\mathrm{HOBO}$ data logger (Onset Computer Corporation, Bourne, MA, USA). The photoperiod was $14 \mathrm{~h}$, and photon flux density (400 to $700 \mathrm{~nm}$ ) provided by cool fluorescent lamps was about $900 \mu \mathrm{mol} \mathrm{m}{ }^{-2} \mathrm{~s}^{-1}$ at the top of the plant canopy. After the completion of Experiment I, the same two growth chambers were used for Experiment II with the same temperature, relative humidity, and light settings. The crop husbandry, temperature regimes, and traits recorded were the same as described below.

\section{Chlorophyll index, chlorophyll $a$ fluorescence, and gas exchange measurements}

At the completion of the heading stage, the main stem of each of 40 plants in each growth chamber was tagged for the measuring of physiological and biochemical traits. All physiological traits were measured on attached fully expanded flag leaves. In both experiments, chlorophyll index, chlorophyll $a$ fluorescence, and gas exchange measurements were measured from five tagged flag leaves at OT and HT on days $0,3,6,9$ and 12 after the start of temperature treatments between 10:00 and 14:00 h. Chlorophyll index was measured using a self-calibrating chlorophyll meter (Soil Plant Analytical Device [SPAD], Model 502, Spectrum Technologies, Plainfield, IL). Thylakoid membrane stability was assessed by measuring chlorophyll $a$ fluorescence using a fluorometer (OS5p, OptiScience, Hudson, NH) after 30 min of dark adaptation of leaves and by determining the ratio of basal fluorescence to maximum fluorescence. Increase in this ratio indicates damage to thylakoid membranes [49]. For other chlorophyll $a$ fluorescence measurements, the leaves were dark adapted for $24 \mathrm{~h}$ to attain a maximum level of maximum fluorescence and a minimum level of heat dissipation [50]. The leaves were continuously irradiated with white actinic light to measure the initial fluorescence in leaves acclimated to irradiation (Fo'), steady-state fluorescence yield ( $\mathrm{Fs}$ ), and maximum fluorescence yield (Fms) of irradiated leaves. By using the above parameters the following chlorophyll $a$ fluorescence parameters were calculated: effective quantum yield of PSII ( $\phi$ PSII $=[\mathrm{Fms}-\mathrm{Fs}] /$ fms); apparent rate of photochemical transport of electrons through PSII $($ ETR $=\phi$ PSII $\times$ PAR $\times 0.5 \times 0.84)$, the coefficient of photochemical quenching $(\mathrm{qP}=[\mathrm{Fms}-\mathrm{Fs}] /$ [Fms -Fo]), and the coefficient of non-photochemical quenching of excitation energy $(\mathrm{NPQ}=[\mathrm{Fm}-\mathrm{Fms}] / \mathrm{fms})$ were calculated by the instrument software $[50,51]$. In addition, leaf level gas exchange measurements (photosynthesis and stomatal conductance) were measured in five leaves using a LICOR 6400 portable photosynthesis system (LICOR, Lincoln, NE). Gas exchange measurements were taken at daytime growth temperature and ambient $\mathrm{CO}_{2}$ conditions $\left(400 \mu \mathrm{mol} \mathrm{mol}^{-1}\right)$. Constant temperature within the chamber was maintained, using the built-in software of the instrument. The internal light-emitting diode (LED) light source in the LICOR 6400 was set at $1600 \mu \mathrm{mol} \mathrm{m} \mathrm{m}^{-2} \mathrm{~s}^{-1}$ to ensure a constant, uniform light across all measurements. 
Leaf collection for xanthine oxidase enzyme activity, hydrogen peroxide radical content, malondialdehyde content, and cell membrane stability

After recording the above physiological traits at day 0, 3, 6,9 and 12 of the temperature treatment, the first, second and third leaves from the top were excised and immediately frozen in liquid nitrogen and stored in -80 ${ }^{\circ} \mathrm{C}$ until further biochemical analyses, which are described in the following sections.

\section{Xanthine oxidase enzyme activity}

The leaves $(100 \mathrm{mg})$ were ground in $1 \mathrm{~mL}$ of phosphate buffer pH 7.5 and centrifuged at $15,000 \mathrm{~g}$ for $10 \mathrm{~min}$ at $4{ }^{\circ} \mathrm{C}$. The supernatant was collected and analyzed for superoxide radical $\left(\mathrm{O}_{2}{ }^{-}\right)$production $\left(30 \mathrm{~min}\right.$ at $\left.37^{\circ} \mathrm{C}\right)$, using xanthine as substrate, according to the kit instructions from the Amplex ${ }^{\circ}$ Red Xanthine Oxidase Assay kit (Molecular Probes, Eugene, OR product number A22182). One enzyme unit was the amount of xanthine oxidase that will form $1 \mu \mathrm{mol}$ of uric acid from hypoxanthine at $25^{\circ} \mathrm{C} \mathrm{g}^{-1}$ on a leaf fresh weight basis [52].

\section{Hydrogen peroxide content}

The leaves $(100 \mathrm{mg}$ ) were ground in $1 \mathrm{~mL}$ of cold acetone and centrifuged at $5000 \mathrm{~g}$ for $10 \mathrm{~min}$ at 4 ${ }^{\circ} \mathrm{C}$, and the supernatant was used for the $\mathrm{H}_{2} \mathrm{O}_{2}$ assay. The $\mathrm{H}_{2} \mathrm{O}_{2}$ content was measured using a onestep assay (Amplex ${ }^{\circ}$ Red hydrogen peroxide/peroxidase assay kit; Invitrogen Molecular Probes, Inc., Eugene, OR, USA, product number A22188), which uses the Amplex ${ }^{\circ}$ Red reagent (10-acetyl-3,7-dihydroxyphenoxazine), in combination with horseradish peroxidase (HRP), to detect $\mathrm{H}_{2} \mathrm{O}_{2}$. In the presence of peroxidase, the Amplex ${ }^{\circ}$ Red reagent reacts with $\mathrm{H}_{2} \mathrm{O}_{2}$ in a $1: 1$ stoichiometry to produce the redfluorescent oxidation product, resorufin, which has an absorption maximum at $560 \mathrm{~nm}$. The background absorbance derived from a no- $\mathrm{H}_{2} \mathrm{O}_{2}$ control was subtracted for all samples and expressed as $\mathrm{nmol} \mathrm{g}^{-1}$ on fresh weight basis [53].

\section{Malondialdehyde content}

Malondialdehyde content in leaf samples was measured using an OxiSelect thiobarbituric acid reactive substances (TBARS) assay kit (Cell Biolabs, San Diego, CA, USA, product number STA 330) as an estimate of lipid peroxidation. The TBARS assay is based on the reactivity of MDA with two molecules of thiobarbituric acid (TBA) via an acid-catalyzed nucleophilic-addition reaction. The resulting pinkish-red fluorescent MDA:TBA (1:2) adduct has an absorbance maximum at $532 \mathrm{~nm}$ and can be measured colorimetrically [54]. In the present study, the estimation of MDA content was done as explained by Narayanan et al. [25].

\section{Cell membrane damage}

Cell membrane damage was measured according to Sairam et al. [55]. Leaf punches ( 100 mg) were placed in $20 \mathrm{~mL}$ of deionized water in two test tubes. One tube was incubated in a water bath at a constant temperature of $40{ }^{\circ} \mathrm{C}$ for $30 \mathrm{~min}$, and its conductivity $\left(\mathrm{C}_{1}\right)$ was measured with a conductivity meter. The second tube was placed in a boiling water bath $\left(100{ }^{\circ} \mathrm{C}\right)$ for $10 \mathrm{~min}$, cooled, and conductivity was recorded $\left(\mathrm{C}_{2}\right)$. Cell membrane damage (i.e., ion leakage) was expressed as a percentage using the formula: $\left[1-\left(C_{1} / C_{2}\right)\right] \times 100$.

\section{Antioxidant enzyme activities}

For SOD, CAT, POX, and glutathione peroxidase (GPX) enzyme assays, frozen leaf samples were homogenized in $1 \mathrm{~mL}$ of ice-cold $0.1 \mathrm{M}$ Tris- $\mathrm{HCl}$ buffer, $\mathrm{pH} 7.8$, per gram fresh weight. The homogenate was centrifuged at $20,000 \mathrm{~g}$ for $15 \mathrm{~min}$ at $4{ }^{\circ} \mathrm{C}$. The supernatant was used for measuring enzyme activity.

\section{Superoxide dismutase enzyme activity}

Total SOD activity was measured on the supernatant with a superoxide dismutase assay kit (Cayman Chemical, Ann Arbor, Michigan, USA, product number 706002) according to manufacturer's instructions. This kit utilizes a tetrazolium salt for detection of superoxide radicals generated from oxygen by xanthine oxidase acting on hypoxanthine. One unit of SOD is the amount of enzyme needed to obtain $50 \%$ dismutation of superoxide radical on leaf fresh weight basis [56].

\section{Catalase enzyme activity}

The catalase enzyme activity was measured using Amplex ${ }^{\oplus}$ Red catalase assay kit (Molecular Probes, Invitrogen, Inc., Eugene, OR, USA, product number A22180), as it provides an ultrasensitive, simple assay method for measuring CAT activity. In the assay, CAT first reacts with $\mathrm{H}_{2} \mathrm{O}_{2}$ to produce water and oxygen $\left(\mathrm{O}_{2}\right)$. Next, the Amplex red reagent (10-acetyl-3,7-dihydroxyphenoxazine) reacts with a 1:1 stoichiometry with any unreacted $\mathrm{H}_{2} \mathrm{O}_{2}$ in the presence of HRP to generate the red-fluorescent oxidation product, resorufin, which has an absorption maximum at $560 \mathrm{~nm}$. One enzyme unit was the amount of catalase enzyme that decomposes $1.0 \mu \mathrm{mol}$ of $\mathrm{H}_{2} \mathrm{O}_{2} \mathrm{~min}^{-1} \mathrm{~g}^{-1}$ of tissue on leaf fresh weight basis at $25^{\circ} \mathrm{C}$ [57].

\section{Peroxidase enzyme activity}

The peroxidase (POX) enzyme activity was measured using a Amplex ${ }^{\circ}$ Red hydrogen peroxide/peroxidase assay kit (Molecular Probes, Invitrogen, Inc., Eugene, OR, USA, product number A 22188), which is a onestep assay that uses the Amplex ${ }^{\circ}$ Red reagent (10-acetyl3,7-dihydroxyphenoxazine) to detect POX activity. The 
POX enzymatic activity was determined following the same procedure as the determination of $\mathrm{H}_{2} \mathrm{O}_{2}$ except that the Amplex Red reagent contained $2 \mathrm{mmol} \mathrm{H}_{2} \mathrm{O}_{2}$ instead of HRP. One enzyme unit is the amount of enzyme that will form $1.0 \mathrm{mg}$ purpurogallin from pyrogallol in $20 \mathrm{~s}$ at $\mathrm{pH} 6.0$ and $20^{\circ} \mathrm{C}$ on leaf fresh weight basis [58].

\section{Glutathione peroxidase enzyme activity}

The GPX was assayed using a Cayman's GPX assay kit (Cayman Chemical, Ann Arbor, MI, product number 703102). The GPX activity was measured indirectly by a coupled reaction with glutathione reductase (GR). Oxidized glutathione (GSSG), produced upon reduction of hydroperoxide by GPX, is cycled to its reduced state by GR and NADPH. The oxidation of $\mathrm{NADPH}$ to $\mathrm{NADP}^{+}$is accompanied by a decrease in absorbance at $340 \mathrm{~nm}$. Under conditions in which the GPX activity is rate limiting, the rate of decrease in the absorbance at $340 \mathrm{~nm}$ is directly proportional to the GPX activity in the sample. To each well of a microplate, $100 \mu \mathrm{L}$ of assay buffer $(50 \mathrm{mM}$ Tris- $\mathrm{HCl}$, $\mathrm{pH} 7.6$ containing $5 \mathrm{mM}$ EDTA), $50 \mu \mathrm{L}$ of cosubstrate mixture (used as provided by manufacture, lyophilized powder of NADPH, glutathione and glutathione reductase) and $20 \mu \mathrm{L}$ of sample was added. For background or non-enzymatic controls, $120 \mu \mathrm{L}$ of assay buffer and $50 \mu \mathrm{L}$ of co-substrate were added. Similarly, for positive controls, $100 \mu \mathrm{L}$ of assay buffer, $50 \mu \mathrm{L}$ of co-substrate mixture and $20 \mu \mathrm{L}$ of diluted GPX (1:50; control) were added. The reaction was initiated by adding $20 \mu \mathrm{L}$ of cumene hydroperoxide (used as supplied) to all wells. The microplate was carefully shaken for a few sec to mix the samples and reagent. The absorbance at $340 \mathrm{~nm}$ was read every min for 5 min using an Epoch spectrophotometer (BioTek, Winooski, VT, USA). The change in absorbance at $340 \mathrm{~nm} \mathrm{~min}{ }^{-1}$ was calculated for each sample. The absorbance by background was subtracted from the sample to get the actual change in absorbance due to the enzyme in the sample. One unit enzyme will oxidize $1 \mathrm{nmol}$ of NADPH to $\mathrm{NADP}^{+} \mathrm{min}^{-}$ ${ }^{1}$ on leaf fresh weight basis [59].

\section{Lipid extraction and ESI-MS/MS lipid profiling in leaves}

At each temperature regime on 10th d of HT stress, the flag leaf was collected between 10:00 and 11:00 h. At sampling, the middle one third of each flag leaf was cut and immediately chopped into pieces and transferred to $6 \mathrm{~mL}$ of isopropanol with $0.01 \%$ BHT at $75{ }^{\circ} \mathrm{C}$ in a 50 $\mathrm{mL}$ glass tube with a Teflon-lined screw cap (Thermo Fisher Scientific, Inc., Waltham, MA, USA). Lipid extraction was performed as described by Narayanan et al. [25]. An automated electrospray ionization-tandem mass spectrometry approach was used for analysis. Polar and oxidized lipid profiling were carried out as described previously $[25,60]$. Double bond index was calculated as per Narayanan et al. [25]. A response factor was applied to the galactolipids; data calculated in comparison to the saturated internal standards was divided by 2.8 to account for the greater response of the mass spectrometer to unsaturated lipids when analyzed as $\left[\mathrm{M}+\mathrm{NH}_{4}\right]^{+}$ adducts. Triacylglycerols were determined using the approach described by Li et al. [61]; response factor values were taken from Li et al. [61].

\section{Leaf anatomy using scanning electron microscope (SEM)}

At each temperature regime on 10th d of HT stress, the flag leaf was harvested between 10:00 and 11:00 h and imaged soon after picking. The middle portion of flag leaf was cut into small pieces. The upper or lower portion of the leaf was mounted on double stick carbon tape affixed on a carbon stub and viewed with SEM. Similarly, the cross-section area of the leaf was mounted by affixing in vertical position and viewed with SEM (Nova NanoSEM 430, FEI, Hillsboro, OR) using a vCD detector (low voltage high Contrast Detector). The SEM was operated in a beam deceleration mode at a landing energy of $760 \mathrm{eV}$, under high vacuum, $3.5 \mathrm{kV}$, with a spot size of 2.5. The images were taken at 500, 1000, 2000 and $4000 \mathrm{x}$ magnification. However, for viewing the cross section of the leaf, the SEM was operated under low vacuum mode, $3.5 \mathrm{kV}$, with a spot size of 4.0, and the image was captured using a vCD detector. Images depicting $10,20,30,40$ and $50 \mu \mathrm{m}$ were obtained.

Leaf anatomy using transmission electron microscope (TEM) At each temperature regime on the 10th d of HT stress, a flag leaf was collected between 10:00 and 11:00 h. The leaf sample was fixed immediately in $4 \%$ glutaraldehyde in $100 \mathrm{mM}$ sodium cacodylate buffer, $\mathrm{pH}$ 7.2. Following aldehyde fixation, samples were post-fixed in $2 \%$ osmium tetroxide in the same cacodylate buffer, stained in $1 \%$ aqueous uranyl acetate for $8 \mathrm{~h}$, dehydrated in acetone, and embedded in Spurr's resin. Ultrathin sections $(<$ $100 \mathrm{~nm}$ thick) were made using an ultramicrotome, examined with a CM 100 TEM (FEI Company, Hillsboro, OR, USA), and photographed for image analysis with an AMT digital image capture system.

\section{Yield and its components}

For each temperature treatment, the spikes of the main tiller of plants were tagged and used for calculating seed set percentage [4]. At maturity, plants were handharvested by cutting at the potting soil level. Vegetative parts and spikes (main spike and other spikes separately) were dried at $65{ }^{\circ} \mathrm{C}$ for $7 \mathrm{~d}$ and $40{ }^{\circ} \mathrm{C}$ for $10 \mathrm{~d}$, respectively, for determination of dry weight. Grain number per main spike was counted manually. Seed set was 
determined as the ratio of florets with grain to the total number of florets, and expressed as a percentage [4]. The other spikes were also hand threshed to separate grains and counted manually. Seed size was calculated by dividing the total grain weight by number of grains.

\section{Statistical analyses}

Data were analyzed using PROC GLM in the SAS software [62]. The experimental design was a randomized complete block. Plants for different treatments were selected randomly and randomly arranged within each growth chamber (treatments). Growth chamber temperatures were also randomly assigned. The data of each experiment were analyzed separately and in combination (pooled analysis) for physiological, biochemical and lipid traits. The results of both experiments separately or in combination had similar responses and significance for all traits, so data were combined for reporting. For all measured observations standard errors were shown as an estimate of variability, and means were separated using LSD at probability level of 0.05 . For lipid analysis, significance was determined at $P \leq 0.05$, after correcting for the false discovery rate, using Excel 2010. Comparisons were between stress samples and their controls. The lipids and grain yield data from OT and HT plants were uploaded to MetaboAnalyst (metabolanalyst.ca) for correlation analysis using Spearman's rank method, to identify the lipid species that had the strongest relationship with grain yield. The top five lipid species having positive or negative relationships with grain yield were presented. The lipid species having highest positive or negative relationship were regressed against grain yield using SigmaPlot, version 14.0 and presented.

\section{Results}

\section{Quality control of growth chambers}

Mean daytime and nighttime temperatures in all growth chambers were $\pm 0.5{ }^{\circ} \mathrm{C}$ of the target day and night temperatures, and relative humidity was within $\pm 10 \%$ of the target. Our earlier study showed that there is no variation in growth (plant height: 64.0 \pm $0.9 \mathrm{~cm}$; tiller numbers plant $^{-1}: 3.5 \pm 0.1$; spike number per plant: $2.6 \pm 0.1$; and shoot biomass: $3.7 \pm 0.2 \mathrm{~g}$ plant $^{-1}$ ) of the spring wheat genotype Pavon grown in these growth chambers set at $20 / 15{ }^{\circ} \mathrm{C}, 85 \% \mathrm{RH}$ and $12 \mathrm{~h}$ photoperiod [63]. This implies that the growth chamber used for the present experiment had uniform environmental conditions. Apart from this, the same growth chambers were constantly checked for temperature by digital thermometer. The temperature control and growth chamber performance were previously described $[63,64]$.

\section{Effect of HT on physiological traits}

Significant effects of temperature $(P \leq 0.001)$, day of observation $(\mathrm{P} \leq 0.001)$ and interaction of temperature and day of observation $(\mathrm{P} \leq 0.001)$ were observed for chlorophyll index (SPAD units), thylakoid membrane damage (Fo/Fm ratio), stomatal conductance $\left(\mathrm{mmol} \mathrm{m} \mathrm{m}^{-2} \mathrm{~s}^{-1}\right)$, photosynthetic rate $\left(\mu \mathrm{mol} \mathrm{m} \mathrm{m}^{-2} \mathrm{~s}^{-1}\right)$, effective PSII quantum yield $(\phi)$, photochemical quenching $(\mathrm{qP})$ and nonphotochemical quenching (NPQ), and electron transport rate (ETR; $\mu \mathrm{e}^{-1} \mathrm{~mol} \mathrm{~m}^{-2} \mathrm{~s}^{-1}$ ) (Fig. 1). The chlorophyll index and photosynthetic rate were lower, starting at $6 \mathrm{~d}$ of HT stress (Fig. 1a, d), whereas stomatal conductance was lower from $3 \mathrm{~d}$ of HT stress (Fig. 1c). The thylakoid membrane damage at HT was higher starting at $3 \mathrm{~d}$ of stress (Fig. 1b). Irrespective of day of observation, HT stress lowered the chlorophyll index, stomatal conductance and photosynthetic rate by 8,8 , and $16 \%$, respectively (Fig. 1a-d). However, the thylakoid membrane damage was higher by $31 \%$ over OT (Fig. 1b). Regardless of days of observation, HT decreased the effective quantum yield (15\%, Fig. 1e), photochemical quenching (20\%, Fig. 1f), and electron transport rate (20\%, Fig. 1h) in comparison with OT. In contrast, the non-photochemical quenching was higher at HT (Fig. 1g, 35\%) compared with OT.

\section{Effect of HT on oxidant production, MDA content, membrane damage, and antioxidant enzyme activities}

Significant differences in $\mathrm{O}_{2}{ }^{-}, \mathrm{H}_{2} \mathrm{O}_{2}$, and MDA concentrations were observed beginning at $6 \mathrm{~d}$ of HT stress (Fig. 2a-c). Significant differences in cell membrane damage were observed beginning at $9 \mathrm{~d}$ of HT stress (Fig. 2d). $\mathrm{O}_{2}{ }^{-}$content $(P \leq 0.001), \mathrm{H}_{2} \mathrm{O}_{2}$ content $(\mathrm{P} \leq 0.001)$, MDA formation $(\mathrm{P} \leq 0.001)$, and cell membrane damage $(\mathrm{P} \leq$ 0.001) were higher at HT than OT (Fig. 2a, b, c, and d). Averaged across all dates of observation, HT stress increased $\mathrm{O}_{2}{ }^{-}$and $\mathrm{H}_{2} \mathrm{O}_{2}$ content by 27 and $18 \%$, respectively, compared with OT (Fig. 2a, b). Likewise, HT increased MDA and cell membrane damage by 12 and $25 \%$, respectively, compared with OT (Fig. 2c, d). Significant $(\mathrm{P} \leq 0.001)$ differences in SOD, CAT, POX, and GPX enzyme activities were observed from $3 \mathrm{~d}$ of HT stress. Overall, HT stress significantly decreased SOD, CAT, POX and GPX enzyme activities by $12,14,17$, and $15 \%$, respectively, compared with OT (Fig. 2e-h).

\section{Effect of HT on polar lipids and TAG}

HT stress resulted in significant decreases in monogalactosyldiacylglycerol (MGDG) and phosphatidylglycerol (PG), phosphatidylcholine (PC) and phosphatidic acid (PA). The lysophospholipids, lysophosphatidylglycerol (LPG), lysophosphatidylcholine (LPC), and lysophosphatidylethanolamine (LPE), significantly $(P \leq 0.05)$ decreased under HT stress compared with OT (Table 1). HT stress caused a decrease in the amount of more 


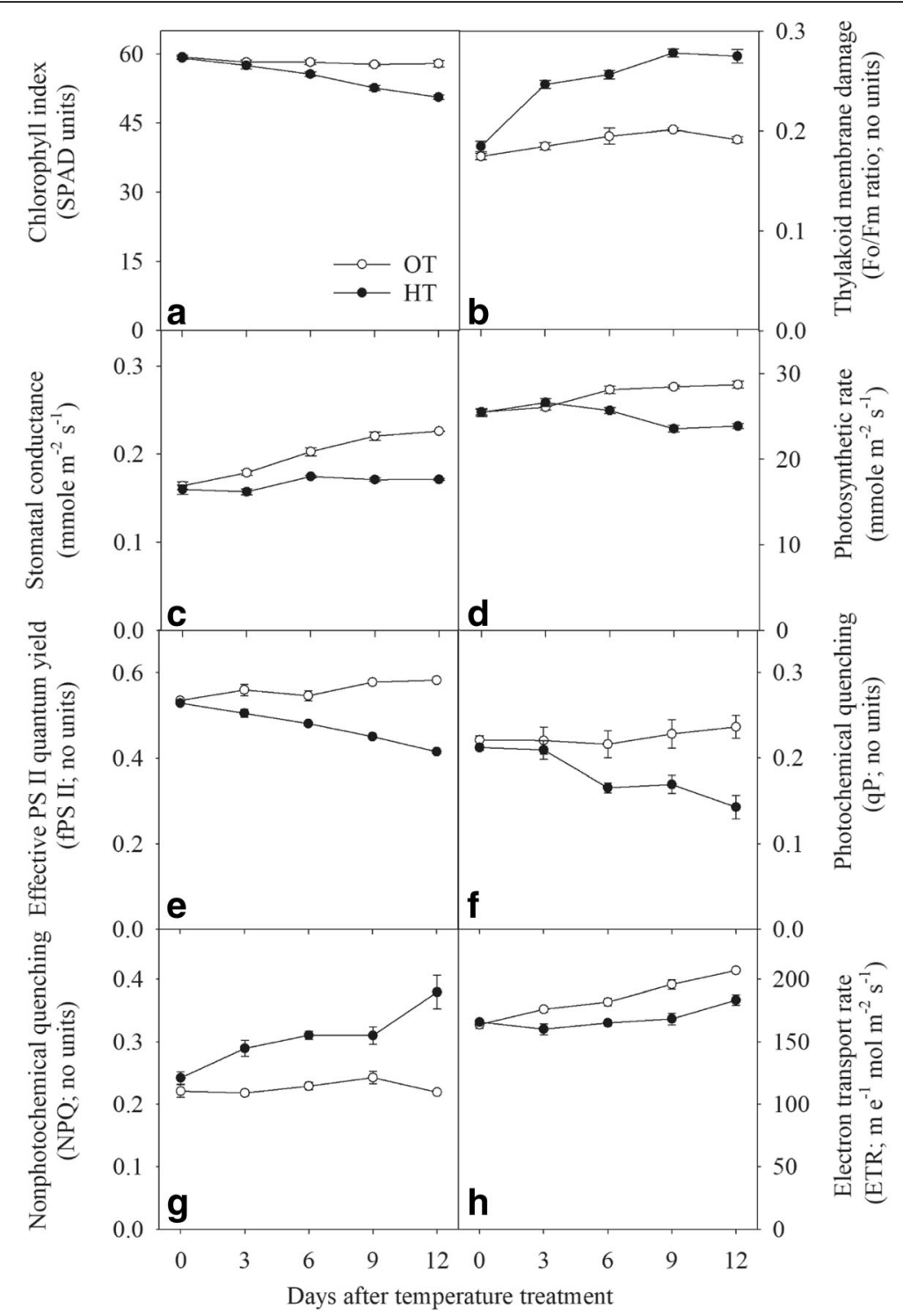

Fig. 1 Effects of temperature (OT: $25 / 15^{\circ} \mathrm{C}$ : daytime maximum/nighttime minimum temperature and $\left.\mathrm{HT}: 35 / 25^{\circ} \mathrm{C}\right)$ during booting stage of wheat genotype Chinese Spring on a chlorophyll index (SAPD units), $\mathbf{b}$ thylakoid membrane damage (Fo/Fm ratio; dimensionless), $\mathbf{c}$ stomatal conductance $\left(\mathrm{mmol} \mathrm{m} \mathrm{m}^{-2} \mathrm{~s}^{-1}\right), \mathbf{d}$ photosynthetic rate $\left(\mu \mathrm{mol} \mathrm{m} \mathrm{m}^{-2} \mathrm{~s}^{-1}\right)$, e effective PSII quantum yield (dimensionless), $\mathbf{f}$ photochemical quenching (dimensionless), $\mathbf{g}$ non-photochemical quenching (dimensionless), and $\mathbf{h}$ electron transport rate $\left(\mu \mathrm{mol} \mathrm{e}^{-1} \mathrm{~m}^{-2} \mathrm{~s}^{-1}\right)$ of wheat genotype Chinese Spring. Values shown are mean \pm SE; $n=10$ (two experiments with five replications each, combined). Vertical bars denote \pm S.E. of means. OT, optimum temperature; $\mathrm{HT}$, high temperature

unsaturated lipid species and an increase in the amount of less unsaturated lipid species (Fig. 3). Many species containing two polyunsaturated acyl chains, such as $36: 6$ (di18:3) species of MGDG, DGDG, PG, PC, PE, PI and PA, 36:5 (18:3/18:2) species of PC, PE, PI, and PA, and 34:4 (18:3/16:1) species of PG and PI decreased under HT stress (Fig. 3). On the other hand, the amount of less unsaturated acyl chains, including 36:5 (18:3/18:2 combination) and $36: 4$ (18:2/18:2 or 18:3/18:1 combination) species of MGDG and DGDG, 34:3 (18:3/16:0 or 18:2/ 16:1) species of PG and PA, 34:2 (18:2/16:0) species of
PE, PI, and PS, and 34:1 (18:1/16:0 or 18:0/16:1) species of DGDG, PG, PC, PE, PI, and PA, increased under HT stress (Fig. 3). These changes led to a decrease in the unsaturation index of most polar lipid classes at HT stress (Fig. 3a, c, d, e, f, g, and h). HT stress decreased the 18:3 acyl species of lysoPC, lysoPE, and lysoPG compared with OT (Fig. 4). A significant $(P \leq 0.05)$ increase in total TAG content was observed under HT stress compared with OT, without a change in unsaturation index (Fig. 5). Acylated MGDG (acMGDG) species are formed by acylation of MGDG on the carbon at the 6-position of 


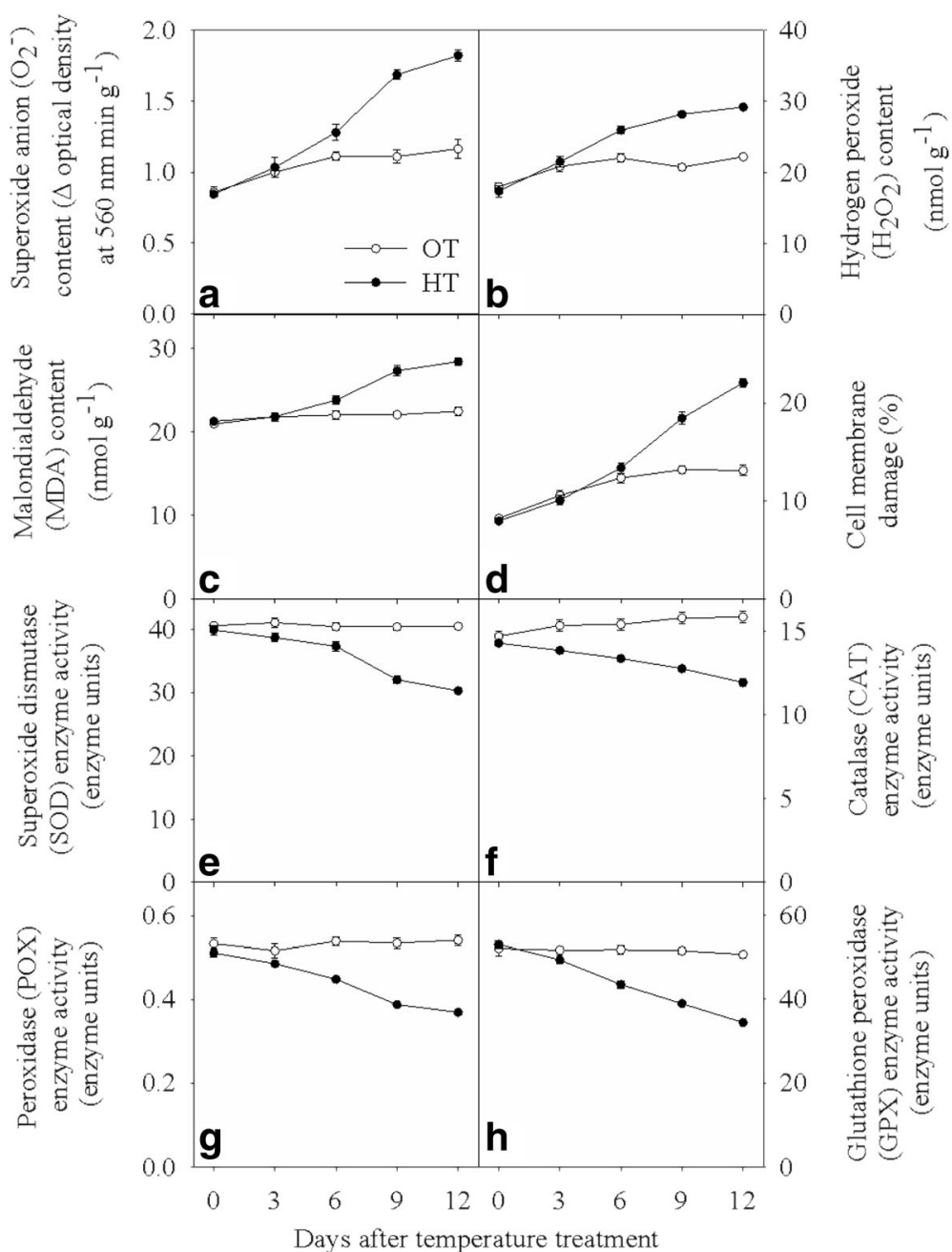

Fig. 2 Effects of temperature (OT: $25 / 15^{\circ} \mathrm{C}$ : daytime maximum/nighttime minimum temperature and $\mathrm{HT}: 35 / 25^{\circ} \mathrm{C}$ ) during booting stage on a superoxide radical content $\left(\Delta\right.$ optical density $\left.\min ^{-1} \mathrm{~g}^{-1}\right)$, $\mathbf{b}$ hydrogen peroxide content $\left(\mathrm{nmol} \mathrm{g}{ }^{-1}\right), \mathbf{c}$ malondialdehyde content $\left(\mathrm{nmol} \mathrm{g}^{-1}\right)$, $\mathbf{d}$ cell membrane damage (\%), e superoxide dismutase enzyme activity (enzyme units), $\mathbf{f}$ catalase enzyme activity (enzyme units), $\mathbf{g}$ peroxidase enzyme activity (enzyme units) and $\mathbf{h}$ glutathione peroxidase enzyme activity (enzyme units) of wheat genotype Chinese Spring. Values shown are mean $\pm \mathrm{SE} ; n=10$ (two experiments and five replications). Vertical bars denote \pm S.E. of means. OT, optimum temperature; HT,

high temperature

galactose (Additional file 1: Figure S1). Acylated MGDG amounts were increased by high temperature stress (Additional file 1: Figure S1).

\section{Effect of HT on molecular species with oxidized fatty acyl chains (oxidized lipids)}

HT stress caused significant $(\mathrm{P} \leq 0.05)$ variation in putative membrane lipids putatively containing oxidized acyl chains (Fig. 6). Species of oxidized PC, PE, and MGDG were observed. Oxidized chain identification by mass spectrometry was based on detection of oxidized lipids' nominal masses, and in some cases, water losses detected by mass spectrometry of the fatty acyl chains [25]. The acyl species are indicated by "acyl carbons:double bond equivalents beyond the acid carbonyl-number of oxygens in addition to the carbonyl group". For example, 18:3-2O, indicates three double bond equivalents and two oxygens beyond the carbonyl group; 18:3-2O might be a hydroperoxide or a ketol derived from 18:3. Similarly, 17:4-2O indicates a 17-carbon fatty acid with four double bond equivalents and two oxygens in addition to those in the carbonyl group. Its chemical formula was defined previously by accurate mass analysis of wheat leaf extracts [25], but the structure of this modified fatty acid is not known. The galactolipid species 18:3-2O/18:3 MGDG was increased significantly $(P<0.05)$ under HT stress (Fig. 6). The 16:0/17:4-2O and 18:3/17:4-2O oxPC lipid species were increased by $\sim 1.6$ and 1.2 -fold, 
Table 1 Total amount of lipid in each head group class in wheat leaves under OT optimal temperature and HT high temperature. Values are means \pm standard error $(\mathrm{SE} ; n=10)$

\begin{tabular}{lll}
\hline Polar lipid & $\begin{array}{l}\text { OT } \\
\text { Lipid per dry weight }\left(\mathrm{nmol} \mathrm{mg}^{-1}\right)\end{array}$ \\
\hline MGDG & $43.3^{\mathrm{a}} \pm 2.0$ & $36.5^{\mathrm{b}} \pm 5.4$ \\
DGDG & $14.8^{\mathrm{a}} \pm 0.17$ & $14.4^{\mathrm{a}} \pm 0.86$ \\
PG & $12.7^{\mathrm{a}} \pm 0.5$ & $11.7^{\mathrm{b}} \pm 0.7$ \\
PC & $15.3^{\mathrm{a}} \pm 0.009$ & $13.5^{\mathrm{b}} \pm 0.89$ \\
PE & $3.7^{\mathrm{a}} \pm 0.2$ & $3.5^{\mathrm{a}} \pm 0.20$ \\
PI & $2.4^{\mathrm{a}} \pm 0.1$ & $2.4^{\mathrm{a}} \pm 0.1$ \\
PA & $0.29^{\mathrm{a}} \pm 0.03$ & $0.23^{\mathrm{b}} \pm 0.02$ \\
PS & $0.28^{\mathrm{a}} \pm 0.01$ & $0.27^{\mathrm{a}} \pm 0.01$ \\
LPG & $0.082^{\mathrm{a}} \pm 0.1$ & $0.069^{\mathrm{b}} \pm 0.01$ \\
LPC & $0.085^{\mathrm{a}} \pm 0.006$ & $0.062^{\mathrm{b}} \pm 0.005$ \\
LPE & $0.067^{\mathrm{a}} \pm 0.004$ & $0.054^{\mathrm{b}} \pm 0.004$ \\
Total polar lipid & $93.2^{\mathrm{a}} \pm 4.2$ & $83.0^{\mathrm{b}} \pm 9.2$ \\
\hline
\end{tabular}

MGDG monogalactosyldiacylglycerol, DGDG digalactosyldiacylgylcerol, PG phosphatidylglycerol, $P C$ phosphatidylcholine, $P E$ phosphatidylethanolamine, $P I$ phosphatidylinositol, PA phosphatidic acid, PS phosphatidylserine, LPG lysophosphatidylglycerol, $L P C$ lysophosphatidylcholine, $L P E$ lysophosphatidylethanolamine. All polar lipid classes were represented as mean \pm SEM, and the same lower case letter indicates no significant difference at LSD $(a<0.05)$ level between OT optimal temperature, and HT high temperature; different letters indicate a significant difference

respectively by HT stress (Fig. 6). Similarly, the 16:0/ 17:4-2O and 18:2/17:4-2O-containing PE were increased $\sim 1.6$ and 1.9-fold, respectively under HT stress (Fig. 6).

\section{Effect of HT on leaf anatomy}

HT stress caused disintegration of the epicuticular wax layer and formed small rod-like structures on both the abaxial (Fig. 7b, d) and adaxial (Fig. 7h, j) surfaces of leaves, while at OT the epicuticular wax was intact (Fig. 7a, e, g, i). SEM showed no difference in the wax morphology between the abaxial (Fig. 7b, d) and the adaxial (Fig. 7h, j) sides of the HT stressed leaf. Under HT stress, the adaxial epicuticular and cuticular wax layers had apparently fragmented, exposing more mesophyll tissue (Fig. 7j), compared with OT (Fig. 7i). HT stress caused complete to partial closure of stomata (Fig. 7f), while at OT the stomata were fully open (Fig. 7e). HT stress decreased the leaf thickness (Fig. 7n), number of phloem cells and tracheids, and increased the suberization of vessels (Fig. 7p) compared with OT (Fig. $7 \mathrm{~m}, \mathrm{o}$ ).

Analysis of the cellular ultrastructure using TEM indicates that HT stress caused damage to the plasma membrane (Fig. 8b) and the epicuticular layer (Fig. 8d) compared with OT (Fig. 8a, c). The chloroplast and thylakoid membranes were damaged under HT stress (Fig. 8f, h) compared with OT (Fig. 8e, g). Similarly, the mitochondrial membrane and cristae were damaged under HT stress (Fig. 8j), as compared with OT (Fig. 8i). Damaged and discontinuous nuclear envelope and heterochromatin were observed under HT stress (Fig. 8l), whereas, in OT, the nuclear membrane was continuous and euchromatin was observed (Fig. 8k). The rough endoplasmic reticulum (ER) was attached to the nuclear envelope and is coiled under OT (Fig. 8m), while, in HT stress, rough ER was not attached to the nuclear envelope and appeared to be linear (Fig. 8n). The number and size of plastoglobules were greater in HT stress (Fig. 8p) compared with OT (Fig. 8o).

\section{Effect of HT on seed yield and its components}

HT stress resulted in a significant $(P \leq 0.05)$ decreases in stem dry weight and yield components in the primary spike compared to OT (Fig. 9). The seed set and seed yield per plant were decreased by $\sim 24 \%$ (Fig. 9b, d) and stem dry weight (Fig. 9a) was decreased by $8 \%$.

\section{Lipids, HT, and yield}

A Spearman's correlation analysis among yield and lipid levels across the OT and HT samples indicated that several lipids were associated with high yield (Table 2). These lipids were also highest at OT. For example, PC(36:6), with two triply unsaturated fatty acids, was a marker positively associated with optimal conditions and high yield (Fig. 3e), while the not-fully-polyunsaturated MGDG(36:4) was associated with HT and low yield (Fig. 3h). The relationship of levels of these lipids to yield for individual HT and OT samples is shown in Additional file 2: Figure S2a, b.

\section{Discussion}

Taken together, the data indicate that HT stress caused decreased unsaturation of phospholipids and accumulation of TAGs. Increased levels of some oxidized lipids were observed along with increased ROS and lower levels of enzymes that remove ROS. Similarly, unsaturated lipids, particularly those containing trienoic fatty acids were decreased, providing both the potential to reduce lipid oxidation but also loss of a potential sink for $\operatorname{ROS}[15,18]$. Damaged cell membranes, organelles, and wax surfaces were observed, along with a decreased photosynthetic rate, which led to a low biomass and yield in plants subjected to HT.

Lipid changes undoubtedly represent a mixture of effects. Desaturase activity is reduced in response to HT and these changes are adaptive in terms of maintaining the fluidity of the membrane environment (Fig. 3) [35, 36, 65-71]. It's likely that the accumulation of TAGs (Fig. 5), which may occur in observed plastoglobules (Fig. 8) and/or cytosolically, includes acyl chains removed from membrane lipids being remodeled under stress. The lack of difference in unsaturation index of TAGs between leaves of OT and HT plants is consistent with this interpretation. 


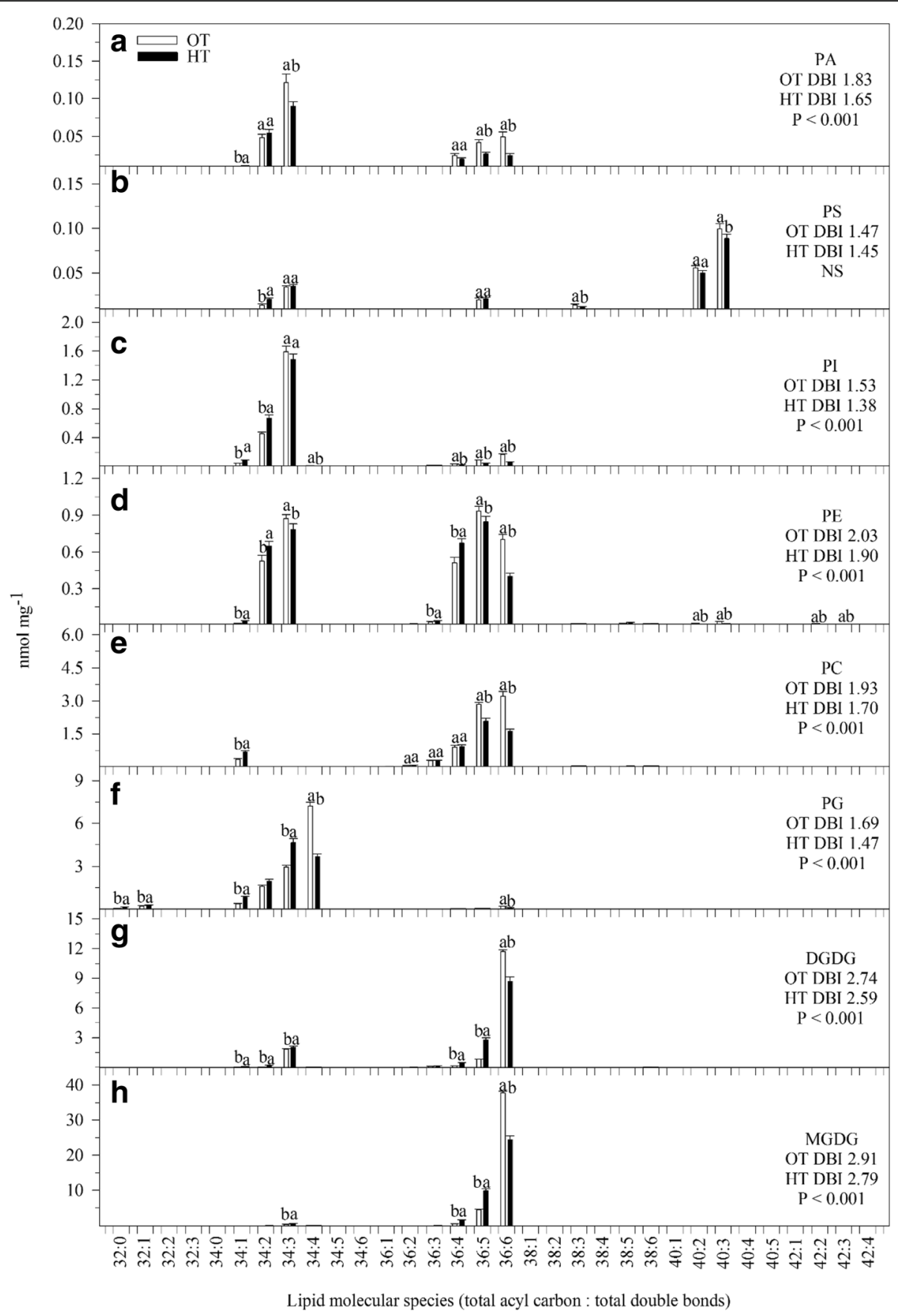

Fig. 3 Effects of temperature $\left(\mathrm{OT}: 25 / 15^{\circ} \mathrm{C}\right.$ : daytime maximum/nighttime minimum temperature and $\left.\mathrm{HT}: 35 / 25^{\circ} \mathrm{C}\right)$ during booting stage on polar lipid molecular species of wheat genotype Chinese Spring (a) PA, phosphatidic acid, (b) PS, phosphatidylserine; (c) PI, phosphatidylinositol; (d) PE, phosphatidylethanolamine; (e) PC, phosphatidylcholine; (f) PG, phosphatidylglycerol; (g) DGDG, digalactosyldiacylglycerol and (h) MGDG, monogalactosyldiacylglycerol. Sampling was on day 10 of the treatment. Values shown are mean $\pm \mathrm{SE} ; n=10$ (two experiments with five replications each, combined). Vertical bars denote \pm S.E. of means. Means with different letters are significantly different according to the least significant difference (LSD) test at $P<0.05$. OT, optimum temperature; HT, high temperature; DBI, double bond (unsaturation) index

Peroxidation of lipids in plants can occur by via lipoxygenases (LOXs), by singlet oxygen generated by photosynthesis, or by radicals $[15,72,73]$. In leaves in the light, most primary lipid peroxidation is by reaction with singlet oxygen, a high energy form of oxygen formed when an excited chlorophyll molecule transfers energy to ground state $\mathrm{O}_{2}$ [74]. In wheat, galactolipids (MGDG and DGDG) are the major chloroplast lipids, and MGDG (36:6) and DGDG (36:6) (each with two 18:3 chains) are the major molecular species. These "36:6" 


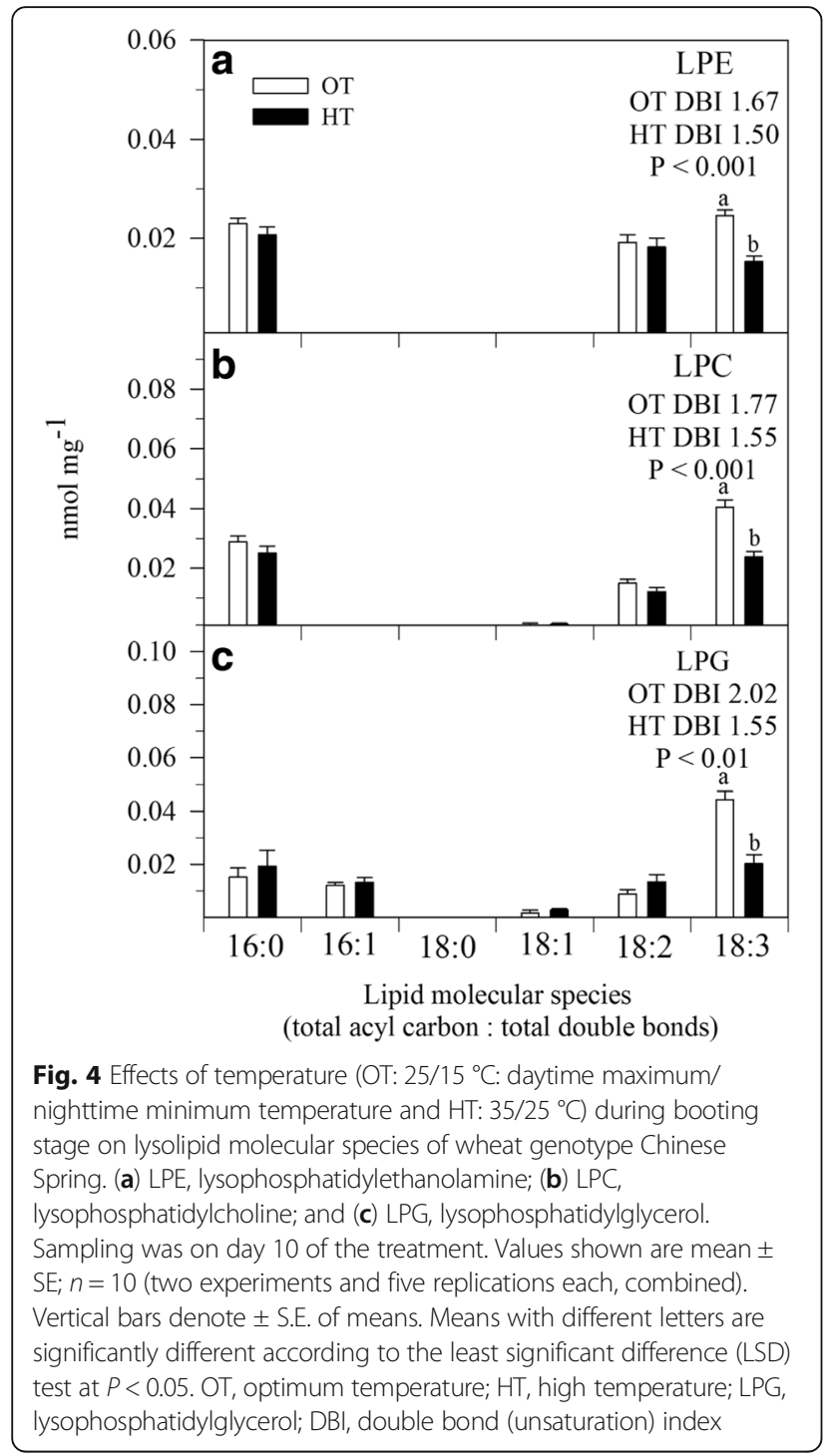

species are particularly vulnerable to peroxidation by singlet oxygen and by LOX. Indeed, MGDG (18:3-2O/ 18:3), which is consistent with being a peroxidized species, is increased in HT (Fig. 6). Peroxidized trienoic fatty acids can undergo chain fragmentation and the pool of peroxides can be amplified; one of the lipid fragmentation products is MDA [14, 15], which was observed to increase in HT. Indeed, the observed greyish to dark material in the thylakoid (Fig. 8b-h) suggests decomposition of thylakoid membrane lipids [75], and the decrease in $\phi$ PSII ratio suggests the occurrence of photoinhibition (Fig. 1e) [76], leading to increased ROS generation and oxidative damage [76-78]. The cumulative result of abiotic stress is generation of three ROS species, singlet oxygen, superoxide radical, and hydrogen peroxide [74, 79]. Interestingly, recent work by the Farmer and Mueller groups demonstrates that trienoiccontaining MGDG may be the sink for MDA and well as

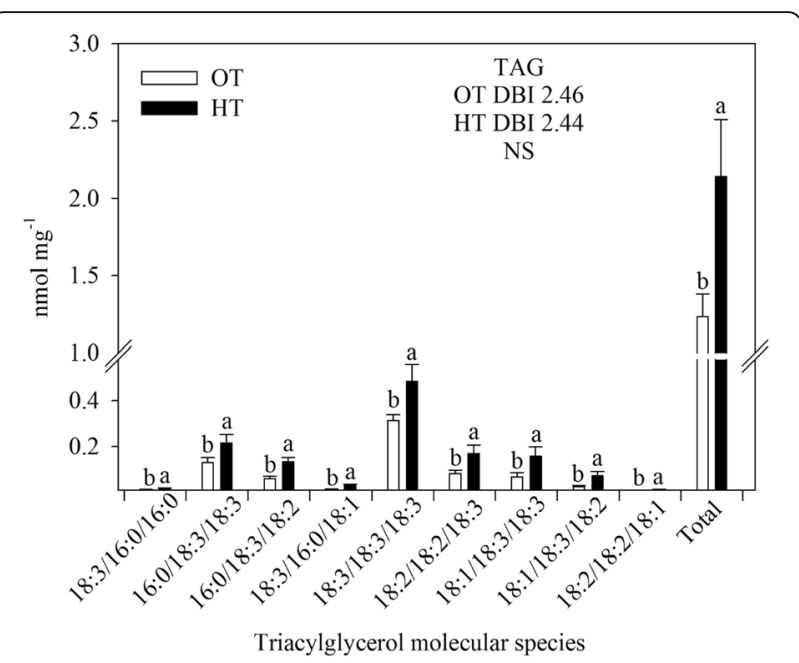

Fig. 5 Effects of temperature (OT: $25 / 15^{\circ} \mathrm{C}$ : daytime maximum/ nighttime minimum temperature and $\mathrm{HT}: 35 / 25^{\circ} \mathrm{C}$ ) during booting stage on triacylglycerol (TAG) in leaves of wheat genotype Chinese Spring. Sampling was on day 10 of the treatment. No positional specificity of the fatty acyl chains on the glycerol was determined, nor is implied. Values shown are mean $\pm \mathrm{SE} ; n=10$ (two experiments and five replications each, combined). Vertical bars denote \pm S.E. of means. Means with different letters are significantly different according to the least significant difference (LSD) test at $P<0.05$. OT, optimum temperature; $\mathrm{HT}$, high temperature

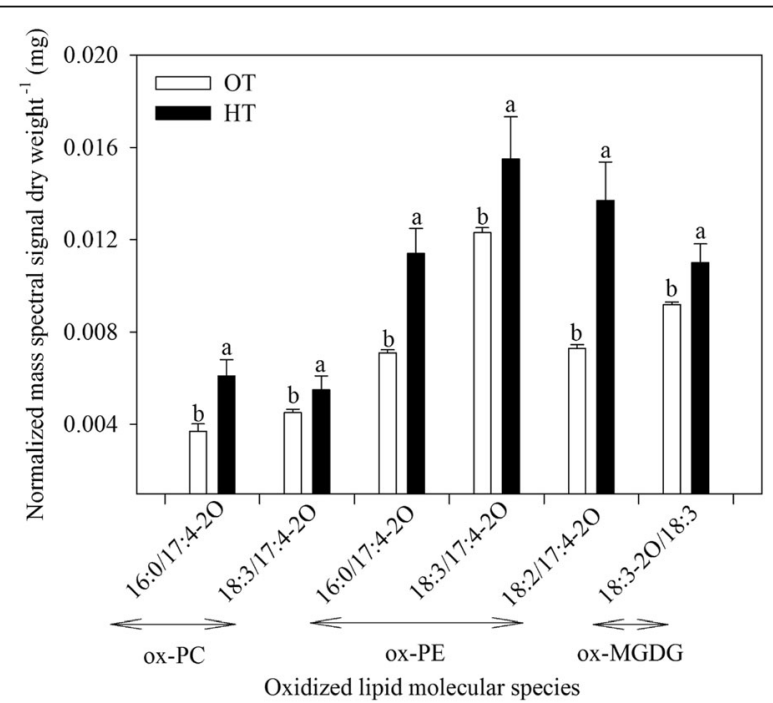

Fig. 6 Effects of temperature (OT: $25 / 15^{\circ} \mathrm{C}$ : daytime maximum/ nighttime minimum temperature and $\mathrm{HT}: 35 / 25^{\circ} \mathrm{C}$ ) during booting stage on content of lipids containing oxidized fatty acids (oxidized lipids) in wheat genotype Chinese Spring. Sampling was on day 10 of the treatment. No positional specificity of the fatty acyl chains is implied. Values shown are mean $\pm \mathrm{SE} ; n=10$ (two experiments and five replications each, combined). Vertical bars denote \pm S.E. of means. Means with different letters are significantly different according to the least significant difference (LSD) test at $P<0.05$. OT, optimum temperature; $\mathrm{HT}$, high temperature; $\mathrm{PC}$, phosphatidylcholine; $\mathrm{PE}$, phosphatidylethanolamine; MGDG, monogalactosyldiacylglycerol 


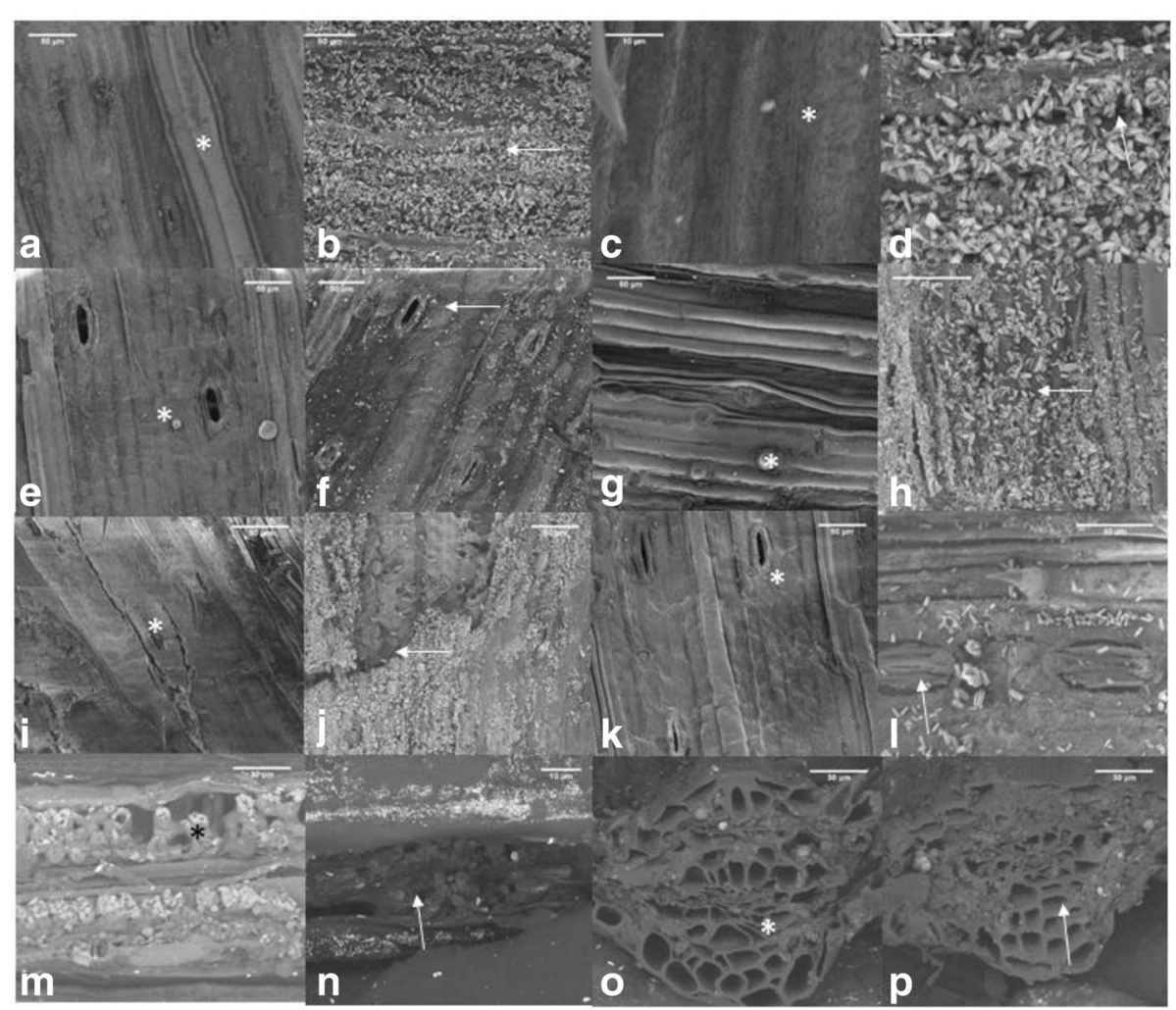

Fig. 7 Effects of temperature $\left(\mathrm{OT}: 25 / 15^{\circ} \mathrm{C}\right.$ : daytime maximum/nighttime minimum temperature and $\left.\mathrm{HT}: 35 / 25^{\circ} \mathrm{C}\right)$ during booting stage on leaf surface morphology. Abaxial surface of OT leaf $(\mathbf{a}, \mathbf{c}, \mathbf{e})$ and $\mathrm{HT}$ stressed leaf $(\mathbf{b}, \mathbf{d}, \mathbf{f})$ showing the disintegration of wax and closure of stomata. Similarly, the adaxial surface of OT $(\mathbf{g}, \mathbf{i}, \mathbf{k})$ and HT stressed leaf $(\mathbf{h}, \mathbf{j}, \mathbf{l})$ showing the integration of wax and closure of stomata. Arrows indicate disintegrated wax and closed stomata under HT stress. The corresponding information in OT is indicated by *. The decreased mesophyll thickness under HT stress is shown in (n) and its corresponding OT was shown as (m). The vascular bundle size and morphology of OT and HT was shown in (o) and (p), respectively. OT, optimum temperature; $\mathrm{HT}$, high temperature

its source $[15,18]$. Thus, the ongoing lowering of " $36: 6$ " galactolipid species levels, as MDA is produced, could potentially contribute to increased MDA levels.

Limitations to $\mathrm{CO}_{2}$ assimilation cause an imbalance between photochemical activity at photosystems and the electron requirement for photosynthesis [78, 80-82]. Physical damage to thylakoid and chloroplast membranes was observed under HT stress (Fig. 8f, h). As observed here, thylakoid membranes have been demonstrated to be more sensitive to HT stress than the chloroplast envelope or other cell compartments [83]. Indeed, excessive ROS accumulation damages pigments and proteins, as well as lipids [84], thereby contributing to oxidative damage. Chlorophyll is primarily located in the thylakoid membranes, where it forms complexes with the proteins of PSII and PSI and damage to thylakoid membranes may lead to chlorophyll loss [78, 82, 85].

Increased ROS content observed under HT is also associated with decreased antioxidant enzyme activities (Fig. 2a-h). Under normal conditions, the rate of production of ROS from electron transport chains is kept under control [12] by antioxidants and antioxidant enzymes.
However, if damage to the thylakoid membranes and/or to the cristae, occurs, then the rate of production of ROS is increased [12], leading to the steady increase in MDA, cell membrane damage, and oxidative damage (Fig. 2c). Under HT stress, the balance between ROS and antioxidant enzyme activity is perturbed (Fig. 2a-h). SOD is usually considered to be the first line of defense against oxidative stress $[12,13]$. High SOD activity can efficiently remove $\mathrm{O}_{2}^{-}$, leading to the production of $\mathrm{H}_{2} \mathrm{O}_{2}$ and its scavenging by CAT, POX and GPX [12, 13]. HT stress decreased all the above antioxidant enzymes activity (Fig. 2e-h) compared with OT. The current results suggest that activity of the antioxidant enzymes in chloroplasts may be downregulated by HT stress, exacerbating accumulation of ROS.

An increase in growth temperature has been directly linked to a decrease in photosynthetic rate (Fig. 1d) [86, 87] by both stomatal and nonstomatal limitations [78, 88], as shown by closed stomata and decreased chlorophyll content, PSII activity, mesophyll cell density, and damaged chloroplast structure $[81,82,85,89,90]$. Excess energy that cannot be used to drive photosynthesis enhances the 


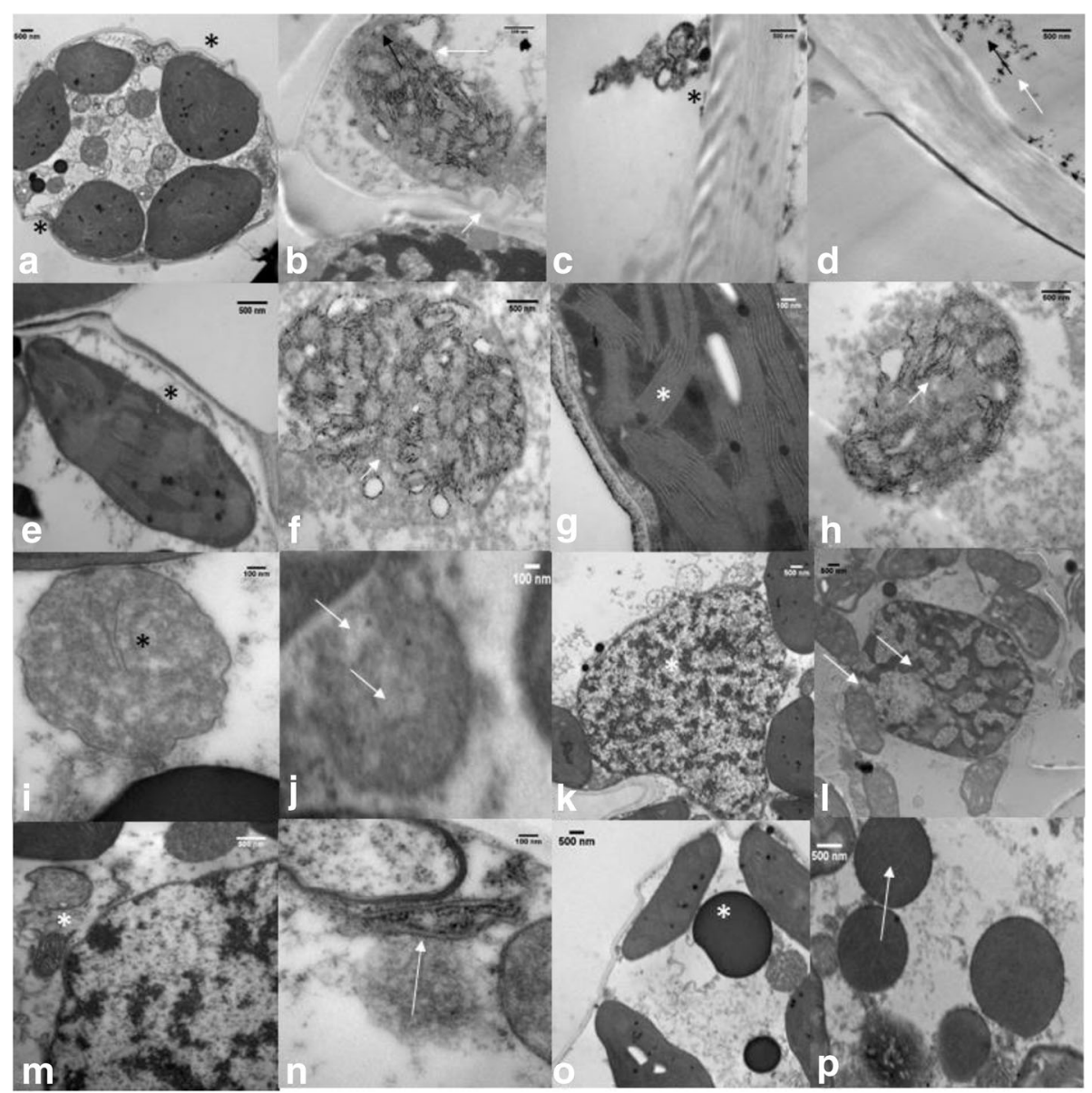

Fig. 8 Effects of temperature $\left(\mathrm{OT}: 25 / 15^{\circ} \mathrm{C}\right.$ : daytime maximum/nighttime minimum temperature and $\left.\mathrm{HT}: 35 / 25^{\circ} \mathrm{C}\right)$ during booting stage on leaf ultrastructure. The OT ( $\mathbf{a}, \mathbf{c}, \mathbf{e}, \mathbf{g}, \mathbf{i}, \mathbf{k}, \mathbf{m}, \mathbf{o})$ and $\mathrm{HT}(\mathbf{b}, \mathbf{d}, \mathbf{f}, \mathbf{h}, \mathbf{j}, \mathbf{I}, \mathbf{n}, \mathbf{p})$ leaf images were showing the normal $\left(^{*}\right)$ and abnormal or damaged (arrow) cell organelles. The image (b) showing the disintegration of cellular membrane, (d) disintegration of wax layer, (f) disintegration of chloroplast membrane, (h) disintegration of thylakoid membrane, (j) disintegration of mitochondrial membrane. The image (I) showing the heterochromation, (n) detached endoplasmic reticulum, and (p) plastoglobule accumulation under HT stress. The corresponding normal structure is shown as *. OT, optimum temperature; $\mathrm{HT}$, high temperature

production of ROS and induces photooxidative damage [77, 91]. An increase in Fo (Fig. 1b) and decrease in $\phi$ PSII (Fig. 1e) indicates damaged PSII reaction centers [88, 92, 93] and impeded transfer of excitation energy from the antenna to the reaction centers $[80,94]$. HT stress decreased qP (Fig. 1f) and ETR (Fig. 1h) by 20\%, indicating both donor and acceptor sides of the reaction center were affected by HT stress [78, 80, 81]. The NPQ increased under HT stress, compared to OT, demonstrating absorbed light energy is not utilized for production of ATP and $\mathrm{NADPH}_{2}$; instead absorbed energy is dissipated as heat [93, 95]. Apart from this, increased thylakoid membranes damage by HT causes proton leakage, leading to decreased $\mathrm{NADPH}_{2}$ production [78]. All these data clearly show occurrence of photoinhibition during HT stress. If this is the case, generation of ROS during photoinhibition could cause chlorophyll degradation, damage to PSII components, and inactivation of enzymes involved in $\mathrm{CO}_{2}$ assimilation [96] and could further explain the reductions in photosynthetic rate in HT stressed plants in the present study.

HT stress decreased the seed set percentage, grain number per spike, and grain yield per spike (Fig. 9). The decrease in grain number was due to decreased seed set $[10,43,97]$. Our previous study in wheat indicates that HT stress caused structural abnormalities to both pollen and pistil [4]. Hence, the decreased seed set may be due to malfunction of both pollen and pistil. The individual grain weight was not influenced by HT stress, because the stress was imposed during booting to anthesis stage. Hence, the decreased grain yield per spike is due to decreased grain number per panicle and decreased photosynthetic rate leading to reduced biomass accumulation.

Chinese Spring was selected for the current study because of its sensitivity to HT stress [98]. It has been widely used in genomic research and its genome is 


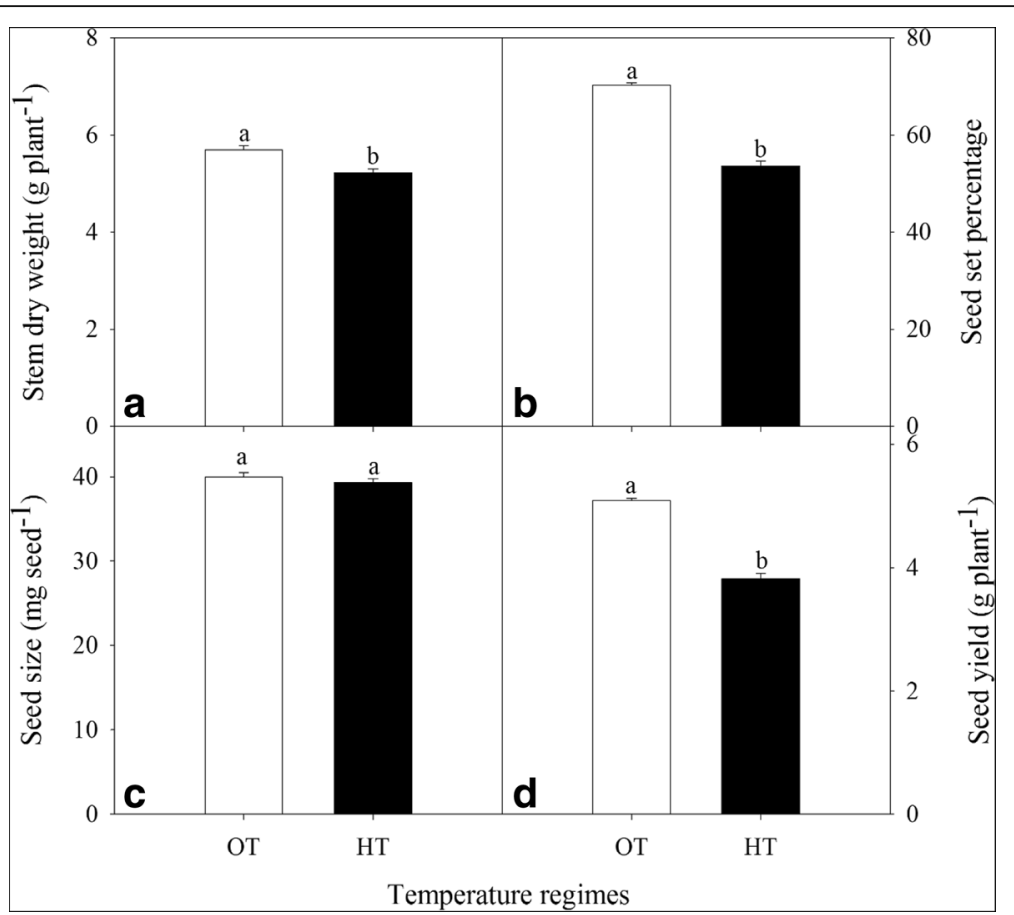

Fig. 9 Effects of temperature $\left(\mathrm{OT}: 25 / 15^{\circ} \mathrm{C}\right.$ : daytime maximum/nighttime minimum temperature and $\left.\mathrm{HT}: 35 / 25^{\circ} \mathrm{C}\right)$ during booting stage on (a) stem dry weight $\left(\mathrm{g} \mathrm{plant}^{-1}\right)$, (b) seed-set percentage, $(\mathbf{c})$ seed size $\left(\mathrm{mg} \mathrm{seed}^{-1}\right)$, and $(\mathbf{d})$ seed yield $\left(\mathrm{g} \mathrm{plant}^{-1}\right)$ of wheat genotype Chinese Spring. Values shown are mean $\pm \mathrm{SE} ; n=20$ (two experiments and ten replications each, combined). Vertical bars denote \pm S.E. of means. Means with different letters are significantly different according to the least significant difference (LSD) test at $P<0.05$. OT, optimum temperature; $\mathrm{HT}$, high temperature

sequenced [99]. There is relatively little information that would allow comparison of lipids and their relationships with HT stress among wheat genotypes, although one study suggests that lipid compositions do vary among genotypes that differ in HT tolerance, and it is reasonable to postulate that this is related to stress tolerance [25].

Table 2 Top five lipid species correlated with grain yield plant $^{-1}$ under OT optimum temperature and HT high temperature conditions

\begin{tabular}{lll}
\hline Relationship & Lipid species & $\begin{array}{l}\text { Spearman's correlation } \\
\text { coefficient }\end{array}$ \\
\hline Lipids positively & PC(36:6) & 0.85 \\
associated with yield & LysoPC(18:3) & 0.84 \\
& PE(42:3) & 0.84 \\
& PC(34:4) & 0.81 \\
& PI(36:6) & 0.79 \\
Lipids negatively & MGDG(36:4) & -0.94 \\
associated with yield & MGDG(36:3) & -0.92 \\
& PG(32:1) & -0.92 \\
& MGDG(34:3) & -0.92 \\
& $\operatorname{DGDG(34:1)}$ & -0.91 \\
\hline
\end{tabular}

OT optimum temperature, $H T$ high temperature

\section{Conclusions}

The present study has shown that the decrease in photosynthetic rate under HT stress is an interplay between thylakoid membrane damage, thylakoid membrane lipid composition, oxidative damage of cell organelle, and stomatal and non-stomatal limitations. Under HT stress accumulation of TAGs without change in unsaturation index as plastoglobules indicates lipid remodeling under stress. The changes in lipid species indicates increases in activities of desaturating, oxidizing, glycosylating and acylating enzymes under HT stress. Cumulative effect of HT stress is generation of ROS, cell organelle damage, plasma and cell organelle membrane damage and reduced antioxidant enzyme activity indicating the imbalance between ROS and antioxidant defense system. The oxidized lipid species identified from this study can be used as a biochemical marker for development of HT stress tolerant wheat genotype. Currently, newer genomic related tools are being used to identify the key target genes that respond to HT stress to facilitate the selection of HT stress tolerant lines. However, comprehensive expression studies on genes involved in thylakoid lipid synthesis, degradation, remodeling will provide more insight into mechanism of tolerance and provide opportunities to direct the wheat breeding program for HT stress tolerance. 


\section{Additional files}

Additional file 1: Figure S1. Effect of high temperature stress on galactose acylation of MGDG species in wheat. Sampling was on day 10 of the treatment. No analysis was performed to indicate the specific positions of the individual acyl chains in the acylated MGDG, which has the usual glycerol-linked fatty acids, plus an additional chain esterified to the galactose [100]. (DOCX $263 \mathrm{~kb}$ )

Additional file 2: Figure S2. Relationship between (a) $P C(36: 6)$ lipid species levels with grain yield plant ${ }^{-1}$ and (b) MGDG(36:4) lipid species levels with grain yield plant ${ }^{-1}$. (DOCX $\left.222 \mathrm{~kb}\right)$

\section{Abbreviations}

DBI: Double bond (unsaturation) index; DGDG: Digalactosyldiacylgylcerol; HT: High temperature; LPC: Lysophosphatidylcholine; LPE: Lysophosphatidylethanolamine; LPG: Lysophosphatidylglycerol; MGDG: Monogalactosyldiacylglycerol; OT: Optimum temperature; PA: Phosphatidic acid; PC: Phosphatidylcholine; PE: Phosphatidylethanolamine; PG: Phosphatidylglycerol: PI: Phosphatidylinositol; PS: Phosphatidylserine; TAG: Triacylglycerol

\section{Acknowledgements}

The authors are grateful to Mary Roth for excellent technical assistance with the lipid analysis, which were performed at the Kansas Lipidomics Research Center Analytical Laboratory; instrument acquisition and lipidomics method development were supported by the National Science Foundation (EPS 0236913, MCB 0920663, MCB 1413036, DBI 0521587, DBI 1228622), Kansas Technology Enterprise Corporation, Kansas IDeA Networks of Biomedical Research Excellence (K-INBRE) (National Institutes of Health P20GM103418), and Kansas State University. The author (M.D) thanks Tamil Nadu Agricultural University, India, for permitting him to perform post-doctoral research at Kansas State University. Mention of trademark or proprietary product does not constitute a guarantee or warranty of the product by Kansas State University or funding agencies and does not imply its approval to the exclusion of other products, which may also be suitable. This publication is Contribution No. 17-213-J from the Kansas Agricultural Experiment Station.

\section{Funding}

We thank the Triticeae Coordinated Agricultural Project (Triticeae-CAP), grant no. 2011-68002-30029, from the USDA NIFA, United States Agency for International Development (USAID) Feed the Future Innovation Lab for Climate Resilient Wheat (Grant no. AID-0AA-A-13-00008); and Innovation Lab for Collaborative Research on Sustainable Intensification (Grant no. AID-0AA-L-14-00006).

\section{Availability of data and materials}

All the data on the present study has been included in the tables and/or figures form in this manuscript; and the datasets used and/or analysed in this study are available from the corresponding author on reasonable request.

\section{Authors' contributions}

PWP conceived and designed the experiments. MD conducted the experiment, collected and analyzed data and wrote the manuscript. DB helped and processed the samples for the electron microscopic imaging. RW helped with protocols for lipid sampling, analyzed and interpreted lipid data and edited manuscript. SVKJ have edited manuscript. All authors read and approved the final manuscript.

Ethics approval and consent to participate

Not applicable.

\section{Consent for publication}

Not applicable.

\section{Competing interests}

The authors declare that they have no competing interests.

\section{Publisher's Note}

Springer Nature remains neutral with regard to jurisdictional claims in published maps and institutional affiliations.

\section{Author details}

'Department of Agronomy, 2004 Throckmorton Plant Sciences Center, Kansas State University, Manhattan, KS 66506, USA. ²Division of Biology, Kansas State University, Manhattan, KS 66506, USA. ${ }^{3}$ Department of Crop Physiology, Tamil Nadu Agricultural University, Coimbatore, India.

Received: 27 December 2017 Accepted: 8 March 2018 Published online: 05 April 2018

\section{References}

1. Cossani CM, Reynolds MP. Physiological traits for improving heat tolerance in wheat. Plant Physiol. 2012;160:1710-8.

2. IPCC. Summary for policymakers. In: Field CB, Barros VR, Dokken DJ, Mach KJ, Mastrandrea MD, Bilir TE, Chatterjee M, Ebi KL, Estrada YO, Genova RC, Girma B, Kissel ES, Levy AN, MacCracken S, Mastrandrea PR, White LL, editors. Climate Change 2014: Impacts, Adaptation, and Vulnerability. Part A: Global and Sectoral Aspects. Contribution of Working Group II to the Fifth Assessment Report of the Intergovernmental Panel on Climate Change. Cambridge, United Kingdom and New York, USA: Cambridge University Press; 2014. p. 1-32.

3. Wollenweber B, Porter JR, Schellberg J. Lack of interaction between extreme high-temperature events at vegetative and reproductive growth stages in wheat. J Agron Crop Sci. 2003;189:142-50.

4. Prasad PW, Djanaguiraman M. Response of floret fertility and individual grain weight of wheat to high temperature stress: sensitive stages and thresholds for temperature and duration. Funct Plant Biol. 2014;41:1261-9.

5. Farooq M, Bramley H, Palta JA, Siddique KHM. Heat stress in wheat during reproductive and grain-filling phases. Crit Rev Plant Sci. 2011;30:1-17.

6. Schapendonk AHCM, Xu HY, van der Putten PEL, Spiertz JHJ. Heat-shock effects on photosynthesis and sink-source dynamics in wheat (Triticum aestivum L.). NJAS Wagening J Life Sci. 2007;55:37-54.

7. Ristic Z, Bukovnik U, Prasad PW. Correlation between heat stability of thylakoid membranes and loss of chlorophyll in winter wheat under heat stress. Crop Sci. 2007;47:2067-73.

8. Yang J, Sears RG, Gill BS, Paulsen GM. Genotypic differences in utilization of assimilate sources during maturation of wheat under chronic heat and heat shock stresses. Euphytica. 2002;125:179-88.

9. Pradhan GP, Prasad PW, Fritz AK, Kirkham MB, Gill BS. Effects of drought and high temperature stress on synthetic hexaploid wheat. Funct Plant Biol. 2012:39:190-8.

10. Prasad PW, Pisipati SR, Ristic Z, Bukovnik U, Fritz AK. Impact of nighttime temperature on physiology and growth of spring wheat. Crop Sci. 2008:48:2372-80.

11. Djanaguiraman M, Prasad PW, Seppanen M. Selenium protects sorghum leaves from oxidative damage under high temperature stress by enhancing antioxidant defense system. Plant Physiol Biochem. 2010:48:999-1007.

12. Noctor $\mathrm{G}$, Foyer $\mathrm{CH}$. Ascorbate and glutathione: keeping active oxygen under control. Annu Rev Plant Physiol Plant Mol Biol. 1998:49:249-79.

13. Mittler R, Vanderauwera S, Gollery M, Breusegem FV. Reactive oxygen gene network of plants. Trends Plant Sci. 2004;9:490-8.

14. Mene-Saffrane L, Dubugnon L, Chetelat A, Stolz S, Gouhier-Darimont C, Farmer EE. Non-enzymatic oxidation of trienoic fatty acids contributes to reactive oxygen species management in Arabidopsis. J Biol Chem. 2009;284:1702-8.

15. Farmer EE, Mueller MJ. ROS-mediated lipid peroxidation and RES-activated signaling. Ann Rev Plant Biol. 2013;64:429-50.

16. Asada K. Production and scavenging of reactive oxygen species in chloroplasts and their functions. Plant Physiol. 2006;141:391-6.

17. Tian F, Gong J, Zhang J, Zhang M, Wang G, Li A, Wang W. Enhanced stability of thylakoid membrane proteins and antioxidant competence contribute to drought stress resistance in the tasg1 wheat stay-green mutant. J Exp Bot. 2013:64:1509-20.

18. Schmid-Siegert E, Stepushenko O, Glauser G, Farmer EE. Membranes as structural antioxidants: recycling of malondialdehyde to its source in oxidation-sensitive chloroplast fatty acids. J Biol Chem. 2016;291:13005-13.

19. Zoeller M, Stingl N, Krischke M, Fekete A, Waller F, Berger S, Mueller MJ. Lipid profiling of the Arabidopsis hypersensitive response reveals specific 
lipid peroxidation and fragmentation processes: biogenesis of pimelic and azelaic acid. Plant Physiol. 2012;160:365-78.

20. Awasthi R, Bhandari K, Nayyar H. Temperature stress and redox homeostasis in agricultural crops. Front Environ Sci. 2015;17 doi.org/10. 3389/fenvs.2015.00011

21. Taki N, Sasaki-Sekimoto Y, Obayashi T, Kikuta A, et al. 12-oxo-phytodienoic acid triggers expression of a distinct set of genes and plays a role in woundinduced gene expression in Arabidopsis. Plant Physiol. 2005;139:1268-83.

22. Eckardt NA. Oxylipin signaling in plant stress responses. Plant Cell. 2008;20:495-7.

23. Andersson MZ, Hamberg M, Kourtchenko O, Brunnstrom A, McPhail KL, Gerwick WH, Gobel C, Feussner I, Ellerstrom M. Oxylipin profiling of the hypersensitive response in Arabidopsis thaliana. Formation of a novel oxophytodienoic acid-containing galactolipid, arabidopside E. J Biol Chem. 2006;281:31528-37.

24. Muench M, Hsin C-H, Ferber E, Berger S, Mueller MJ. Reactive electrophilic oxylipins trigger a heat stress-like response through HSFA1 transcription factors. J Exp Bot. 2016;67:6139-48.

25. Narayanan S, Tamura PJ, Roth MR, Prasad PW, Welti R. Wheat leaf lipids during heat stress: I. High day and night temperatures result in major lipid alterations. Plant Cell Environ. 2016;39:787-803.

26. Kolupaev YY, Karpets YV, Kosakivska IV. The importance of reactive oxygen species in the induction of plant resistance to heat stress. General Appl Plant Physiol Special issue. 2008:34:251-66.

27. Kumar RR, Goswami S, Sharma SK, Singh K, Gadpayle KA, Kumar N, Rai GK, Singh $\mathrm{M}$, Rai RD. Protection against heat stress in wheat involves change in cell membrane stability, antioxidant enzymes, osmolyte, $\mathrm{H}_{2} \mathrm{O}_{2}$ and transcript of heat shock protein. Int J Plant Physiol Biochem. 2012;4:83-91.

28. Iqbal M, Hussain I, Liaqat $H$, Ashraf MA, Rasheed R, Rehman AU. Exogenously applied selenium reduces oxidative stress and induces heat tolerance in spring wheat. Plant Physiol Biochem. 2015;94:65-103.

29. Yogita K, Madan S, Rani B, Reena K, Munjal R. Trehalose mitigates heat stress- induced damages in wheat seedlings. J Wheat Res. 2015;7:74-8.

30. Narayanan S, Prasad PW, Fritz AK, Boyle DL, Gill BS. Impact of high nighttime and high daytime temperature stress on winter wheat. J Agron Crop Sci. 2015;201:206-18.

31. Balla K, Karsai I, Bencze S, Kiss T, Veisz O. Effect of heat stress on the physiological processes of wheat. Acta Agronomica Hung. 2013;61:1-12.

32. Horvath I, Glatz A, Varvasovszki V, Torok Z, Pali T, Balogh G, Kovacs E, Nadasdi L, Benko S, Joo F, Vigh L. Membrane physical state controls the signaling mechanism of the heat shock response in Synechocystis PCC 6803: identification of hsp17 as a 'fluidity gene'. Proc Natl Acad Sci U S A. 1998;95:3513-8.

33. Orvar BL, Sangwan V, Omann F, Dhindsa RS. Early steps in cold sensing by plant cells: the role of actin cytoskeleton and membrane fluidity. Plant J. 2000:23:785-94.

34. Alfonso M, Yruela I, Almarcegui S, Torrado E, Perez MA, Picorel R. Unusual tolerance to high temperatures in a new herbicide-resistant D1 mutant from Glycine max (L.) Merr. Cell cultures deficient in fatty acid desaturation. Planta. 2001;212:573-82.

35. Hugly S, Kunst L, Browse J, Somerville C. Enhanced thermal tolerance of photosynthesis and altered chloroplast ultrastructure in a mutant of Arabidopsis deficient in lipid desaturation. Plant Physiol. 1989:90:1134-42.

36. Murakami Y, Tsuyama M, Kobayashi Y, Kodama H, lba K. Trienoic fatty acids and plant tolerance of high temperature. Science. 2000;287:476-9.

37. Djanaguiraman M, Prasad PW, Boyle DL, Schapaugh WT. High temperature stress and soybean leaves: leaf anatomy and photosynthesis. Crop Sci. 2011; 51:2125-31.

38. Salem-Fnayou AB, Bouamama B, Ghorbel A, Mliki A. Investigations on the leaf anatomy and ultrastructure of grapevine (Vitis vinifera) under heat stress. Microsc Res Tech. 2011;74:756-62.

39. Zhang JH, Huang WD, Liu YP, Pan QH. Effect of temperature acclimation pretreatment on the ultrastructure of mesophyll cells in young grape plants (Vitis vinifera I.cv. Jingxiu) under cross temperature stresses. J Integr Plant Biol. 2005;47:959-70.

40. Al-Khatib K, Paulsen GM. Mode of high temperature injury to wheat during grain development. Physiol Plant. 1984;61:363-8.

41. Wheeler TR, Hong TD, Ellis RH, Batts GR, Morison JLL, Hadley P. The duration and rate of grain growth, and harvest index of wheat (Triticum aestivum) in response to temperature and $\mathrm{CO}_{2}$. J Exp Bot. 1996;47:623-30.

42. Ferris R, Ellis RH, Wheeler TR, Hadley P. Effect of high temperature stress at anthesis on grain yield and biomass of field-grown crops of wheat. Ann Bot. 1998;82:631-9.
43. Prasad PW, Pisipati SR, Mutava RN, Tuinstra MR. Sensitivity of grain sorghum to high temperature stress during reproductive development. Crop Sci. 2008;48:1911-7.

44. Stone PJ, Nicolas ME. Wheat cultivars vary widely in their response of grain yield and quality to short periods of postanthesis heat stress. Aust J Plant Physiol. 1994:21:887-900.

45. Porter JR, Gawith M. Temperatures and the growth and development of wheat: a review. Eur J Agron. 1999;10:23-36.

46. Kirby EJM. Significant stages of ear development in winter wheat. In: Day W, Atkin RK, editors. Wheat growth and modelling. NATO ASI Series. Series A: life S, vol. 86. London: Plenum Press; 1985.

47. Asseng $S$, Ewert $F$, Martre $P$, et al. Rising temperatures reduce global wheat production. Nat Clim Chang. 2014;5:143-7.

48. Rind D. Climate change-just add water vapor. Science. 1998;281:1152-3.

49. Ristic Z, Bukovnik U, Prasad PW, West M. A model for prediction of heat stability of photosynthetic membranes. Crop Sci. 2008:48:1513-22.

50. Maxwell K, Johnson GN. Chlorophyll fluorescence-a practical guide. J Exp Bot. 2000;51:659-68.

51. van Kooten O, Snel JFH. The use of chlorophyll fluorescence nomenclature in plant stress physiology. Photosynth Res. 1999;25:147-50.

52. Hofer T, Marzetti E, Xu J, Seo AY, Gulec S, Knutson MD, Leeuwenburgh C Dupont-Versteegden EE. Increased iron content and RNA oxidative damage in skeletal muscle with aging and disuse atrophy. Exp Geront. 2008:43:563-70.

53. Shin R, Berg RH, Schachtman DP. Reactive oxygen species and root hairs in Arabidopsis root response to nitrogen, phosphorus and potassium deficiency. Plant Cell Physiol. 2005;46:1350-7.

54. Heath RL, Packer L. Photoperoxidation in isolated chloroplasts: I. Kinetics and stoichiometry of fatty acid peroxidation. Arch Biochem Biophys. 1968;125:189-98.

55. Sairam RK, Deshmukh PS, Shukla DS. Tolerance to drought and temperature stress in relation to increased antioxidant enzyme activity in wheat. J Agron Crop Sci. 1997:178:171-7.

56. Sebastiani M, Giordano C, Nediani C, Travaglini C, Borchi E, Zani M, Feccia M, Mancini M, Petrozza V, Cossarizza A, Gallo P, Taylor RW, d'Amati G. Induction of mitochondrial biogenesis is a maladaptive mechanism in mitochondrial cardiomyopathies. J Am Coll Cardiol. 2007:50:1362-9.

57. Jones $P$, Suggett $A$. The catalase-hydrogen peroxide system. Kinetics of catalatic action at high substrate concentrations. Biochem J. 1968;1 10:617-20.

58. Liu X, Williams CE, Nemacheck JA, Wang J, Subramanyam S, Zheng C, Chen $M-S$. Reactive oxygen species are involved in plant defense against a gall midge. Plant Physiol. 2010;152:985-99.

59. Staimer N, Nguyen TB, Nizkorodov SA, Delfino RJ. Glutathione peroxidase inhibitory assay for electrophilic pollutants in diesel exhaust and tobacco smoke. Anal Bioanal Chem. 2012;403:431-41.

60. Xiao S, Gao W, Chen QF, Chan SW, Zheng SX, Ma J, Wang M, Welti R, Chye ML. Overexpression of Arabidopsis acyl-CoA binding protein ACBP3 promotes starvation-induced and age-dependent leaf senescence. Plant Cell. 2010;22:1463-82.

61. Li M, Baughman E, Roth MR, Han X, Welti R, Wang X. Quantitative profiling and pattern analysis of triacylglycerol species in Arabidopsis seeds by electrospray ionization mass spectrometry. Plant J. 2014;77:160-72.

62. SAS Institute. The SAS users guide, Version 9.1.3. Cary: SAS Inst.; 2003.

63. Pradhan GP, Prasad PW, Fritz AK, Kirkham MB, Gill BS. High temperature tolerance in Aegilops species and its potential transfer to wheat. Crop Sci. 2012:52:292-304.

64. Djanaguiraman M, Prasad PW, Schapaugh WT. High day- or nighttime temperature alters leaf assimilation, reproductive success, and phosphatidic acid of pollen grain in soybean (Glycine max (L.) Merr.). Crop Sci. 2013;53:1594-604.

65. Raison JK, Roberts JKM, Berry JA. Correlations between the thermal stability of chloroplast (thylakoid) membranes and the composition and fluidity of their polar lipids upon acclimation of the higher plant, Nerium oleander, to growth temperature. Biochim Biophys Acta. 1982;688:218-28.

66. Kunst L, Browse J, Somerville C. Altered chloroplast structure and function in a mutant of Arabidopsis deficient in plastid glycerol-3-phosphate acyltransferase activity. Plant Physiol. 1989;90:846-53.

67. Wallis JG, Browse J. Mutants of Arabidopsis reveal many roles for membrane lipids. Prog Lipid Res. 2002:41:254-78.

68. Falcone DL, Ogas JP, Somerville CR. Regulation of membrane fatty acid composition by temperature in mutants of Arabidopsis with alternations in membrane lipid composition. BMC Plant Biol. 2004;4:17. 
69. Larkindale J, Huang B. Changes of lipid composition and saturation level in leaves and roots for heat-stressed and heat-acclimated creeping bentgrass (Agrostis stolonifera). Environ Exp Bot. 2004;51:57-67.

70. Liu X, Yang J, Li B, Yang X, Meng Q. Antisense mediated depletion of tomato chloroplast omega-3 fatty acid desaturase enhances thermal tolerance. J Integr Plant Biol. 2006;48:1096-107.

71. Routaboul JM, Skidmore C, Wallis JG, Browse J. Arabidopsis mutants reveal that short- and long-term thermotolerance have different requirements for trienoic fatty acids. J Exp Bot. 2012;63:1435-43.

72. Foyer $\mathrm{CH}$, Noctor $\mathrm{G}$. Redox homeostasis and antioxidant signaling: a metabolic interface between stress perception and physiological responses. Plant Cell. 2005;17:1866-75.

73. Foyer $\mathrm{CH}$, Shigeoka S. Understanding oxidative stress and antioxidant functions to enhance photosynthesis. Plant Physiol. 2011;155:93-100.

74. Triantaphylides C, Krischke M, Hoeberichts FA, Ksas B, Gresser G, Havaux $M$, van Breusegem $F$, Mueller MJ. Singlet oxygen is the major reactive oxygen species involved in photooxidative damage to plants. Plant Physiol. 2008;148:960-8.

75. Lutz C, Di-Piazza L, Fredersdorf J, Bischof K. The effect of ultra-violet radiation on cellular ultrastructure and photosystem II quantum yield of Alaria esculenta (L.) Greville from Spitsbergen (Norway). Polar Biol. 2015; 39:1957-66

76. Havaux M, Greppin H, Strasser RJ. Functioning of photosystems I and II in pea leaves exposed to heat stress in the presence or absence of light. Planta. 1991;186:88-98.

77. Souza RP, Machadoa EC, Silva JAB, Lagoa AMMA, Silveira JAG. Photosynthetic gas exchange, chlorophyll fluorescence and some associated metabolic changes in cowpea (Vigna unguiculata) during water stress and recovery. Environ Exp Bot. 2004;51:45-56.

78. Mathur S, Agrawal D, Jajoo A. Photosynthesis: response to high temperature stress. J Photochem Photobiol B Biol. 2014;137:116-26.

79. Kim C, Apel K. Singlet oxygen-mediated signaling in plants: moving from flu to wild type reveals an increasing complexity. Photosynth Res. 2013;116:455-64.

80. Brestic M, Zivcak M, Kalaji HM, Carpentier R, Allakhverdiev SI. Photosystem I thermostability in situ: environmentally induced acclimation and genotypespecific reactions in Triticum aestivum L. Plant Physiol Biochem. 2012:57:93-105.

81. Brestic M, Zivcak M, Kunderlikova K, Allakhverdiev SI. High temperature specifically affects the photoprotective responses of chlorophyll b-deficient wheat mutant lines. Photosynth Res. 2016;130:251-66.

82. Chen Y-E, Su Y-O, Zhang C-M, Ma J, Mao H-T, Yang Z-H, Yuan M, Zhang ZW, Yuan S, Zhang H-Y. Comparison of photosynthetic characteristics and antioxidant systems in different wheat strains. J Plant Growth Regul. 2017; https://doi.org/10.1007/s00344-017-9731-5.

83. Sayed $\mathrm{OH}$, Earnshaw MJ, Emes MJ. Photosynthetic responses of different varieties of wheat to high temperature: II. Effect of heat stress on photosynthetic electron transport. J Exp Bot. 1989;40:633-8.

84. Halliwell B, Gutteridge JMC. Free radicals in biology and medicine. Oxford: Clarendon; 2007.

85. Jumrani K, Bhatia VS, Pandey GP. Impact of elevated temperatures on specific leaf weight, stomatal density, photosynthesis and chlorophyll fluorescence in soybean. Photosynth Res. 2017;131:333-50.

86. Wahid A, Gelani S, Ashraf M, Foolad MR. Heat tolerance in plants: an overview. Environ Exp Bot. 2007;61:199-223.

87. Brestic M, Zivcak M, Hauptvogel P, Misheva S, Kocheva K, Yang X, Li X, Allakhverdiev SI. Wheat plant selection for high yields entailed improvement of leaf anatomical and biochemical traits including tolerance to non-optimal temperature conditions. Photosynth Res. 2018; https://doi. org/10.1007/s11120-018-0486-Z

88. Song Y, Chen Q, Ci D, Shao X, Zhang D. Effects of high temperature on photosynthesis and related gene expression in poplar. BMC Plant Biol. 2014; 14:111. https://doi.org/10.1186/1471-2229-14-111.

89. Grassi G, Magnani F. Stomatal, mesophyll conductance and biochemical limitations to photosynthesis as affected by drought and leaf ontogeny in ash and oak trees. Plant Cell Environ. 2005;28:834-49.

90. Ashraf A, Harris PJC. Photosynthesis under stressful environments: an overview. Photosynthetica. 2013;51:163-90

91. Seibert M, Picorel R, Rubin AB, Connolly JS. Spectral, photophysical, and stability properties of isolated photosystem II reaction center. Plant Physiol. 1988;87:303-6
92. Genty B, Briantais J-M, Baker NR. The relationship between quantum yield of photosynthetic electron transport and quenching of chlorophyll fluorescence. Biochim Biophys Acta. 1989;990:87-92.

93. Bolhar-Nordenkampf HR, Long SP, Baker NR, Oquist G, Schreiber U, Lechner EG. Chlorophyll fluorescence as a probe of the photosynthetic competence of leaves in the field: a review of current instrumentation. Funct Ecol. 1989:3:497-514.

94. Sun Y, Liu X, Zhai H, Gao H, Yao Y, Du Y. Responses of photosystem II photochemistry and the alternative oxidase pathway to heat stress in grape leaves. Acta Physiol Plant. 2016;38:232.

95. Ruban AV, Johnson MP, Duffy CDP. The photoprotective molecular switch in the photosystem II antenna. Biochim Biophys Acta. 2012;1817:167-81.

96. Dekov I, Tsonev T, Yordanov I. Effects of water stress and high temperature stress on the structure and activity of photosynthetic apparatus of Zea mays and Helianthus annuus. Photosynthetica. 2000;38:361-6.

97. Prasad PW, Djanaguiraman M. High night temperature decreases leaf photosynthesis and pollen function in grain sorghum. Funct Plant Biol. 2011;38:993-1003.

98. Qin D, Wu H, Peng H, Yao Y, Ni Z, Li Z, Zhou C, Sun Q. Heat stress-responsive transcriptome analysis in heat susceptible and tolerant wheat (Triticum aestivum L.) by using wheat genome array. BMC Genomics. 2008;9:432.

99. Brenchley R, Spannagl M, Pfeifer M, Barker GA, D'Amore R, Allen AM, McKenzie N, Kramer M, Kerhornou A, Bolser D, Kay S, Waite D, Trick M, Bancroft I, Gu Y, Hou NX, Luo MC, Sehgal S, Gill B, Kianian S, Anderson O, Kersey P, Dovrak J, McCombie WR, Hall A, Mayer KFX, Edwards K, Bevan MW Hall N. Analysis of the bread wheat genome using whole-genome shotgun sequencing. Nature. 2012:491:705-10.

100. Critchley C, Heinz E. Characterization and enzymatic synthesis of acyl galactosyl monoglyceride. Biochim Biophys Acta. 1973;326:184-93.

\section{Submit your next manuscript to BioMed Central and we will help you at every step:}

- We accept pre-submission inquiries

- Our selector tool helps you to find the most relevant journal

- We provide round the clock customer support

- Convenient online submission

- Thorough peer review

- Inclusion in PubMed and all major indexing services

- Maximum visibility for your research

Submit your manuscript at www.biomedcentral.com/submit 